\title{
منهج التعامل مع أحاديث الفتن والمستقبل
} محمد سعيد حوَّى"

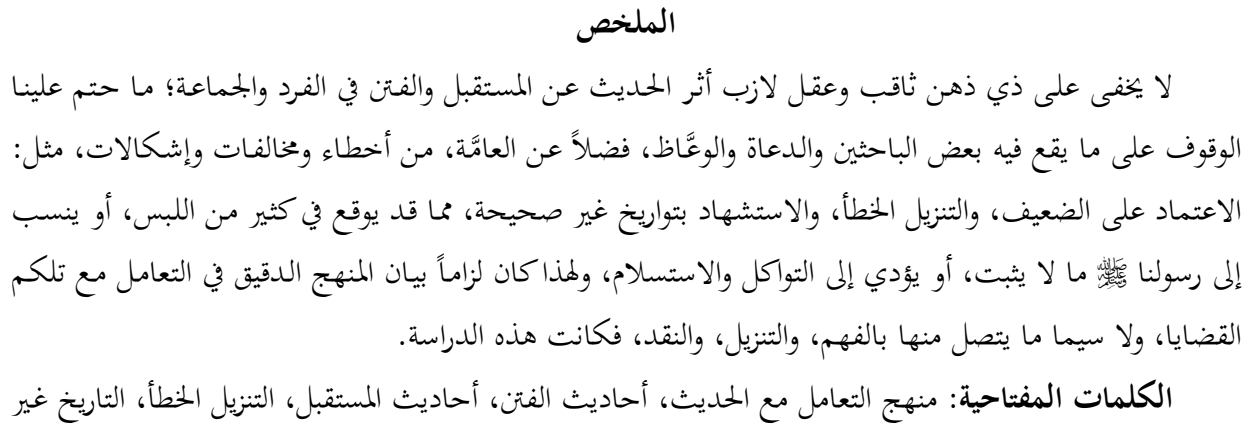

\section{Approaching the Ahadith on Adversities and the Future}

\section{Abstract}

It is undeniable the importance of Prophetic Ahadith (sing. Hadith) telling of adversities (fitnahs) and the future, which highlights the urgent need to examine errors, problems and irregularities made by some researchers, preachers as well as the public. Examples of such problems include reliance on weak Ahadith, inaccurate methodology of applying the text, and using inaccurate dates. Making such mistakes may cause confusion, attributing to the Prophet something he did not say or do, and lead to inappropriate reliance and surrender. The purpose of this paper is to show the importance of explaining the accurate methodology in dealing with these issues, especially as relates to understanding the Ahadith, applying them, and subjecting them to appropriate criticism.

Keywords: Approaching Hadith, Ahadith on adversities, Ahadith on future, Mistaken application, Inaccurate dates

* دكتوراه علوم الحـديث الشـريف، جامعـة بغـداد، أستاذ في جامعـة مؤتــة - كليـة الشـريعة - أصـول الـدين. البريـد الإلكتروني: mshawwa65@ hotmail.com

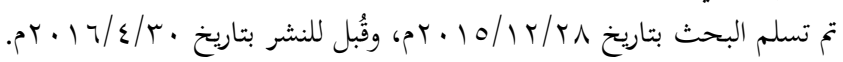




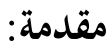

لا يخفى على ذي لُـبِّ مـا لأخبـار المسـتقبل مـن أتخر بـالغ في الـنفس الإنسـانية؛ لاشتمالها على المعلومة والتشويق والإثارة والمتعة أو التخويف، وكذا التوجيه والإرشاد في الكثير من الجوانب التربوية والعملية، فضلاً عن الجحانب العقدي الذي يتعيَّن علينا الإيمان

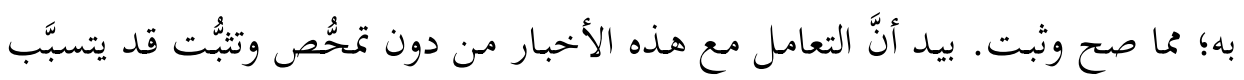
في حدوث أخطاء منهجية خطيرة، وهو ما يحتم إخضاعها للمنهج العلمي الدقيق.

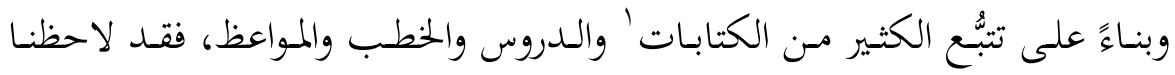
وقوع بعض أصحاها في أخطاء وسقطات قد تفضي إلى التواكل، أو القنوط، أو التسرُّع في اتخـاذ القـرار وإسـقاطه على غـير واقعـه، أو انتشـار ظـاهرة التـدين الشـكلي الفـردي، والنظرة الجزئية إلى القضايا الشرعية، وتبرير الواقع المعيش، وترك العمل للإسلام.

' من الكتب التي ورد فيها كثير من الأخطاء، أو اعتمدت ما لا يصح، أو نزَّلت النصوص تنزيلاً غير صحيح؛ ما يتمت

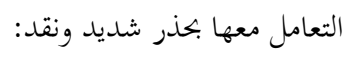

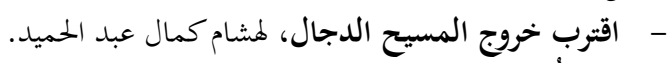

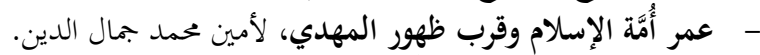

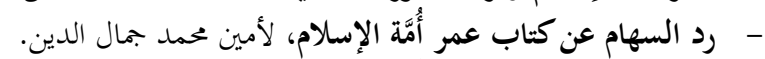

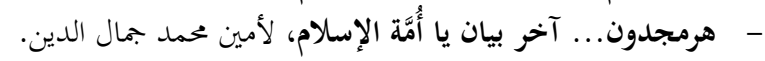

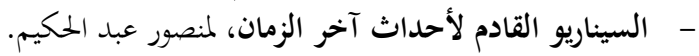

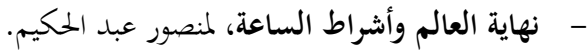

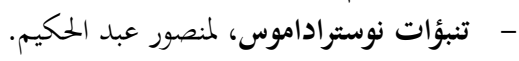

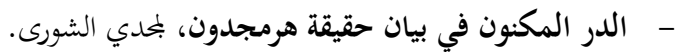

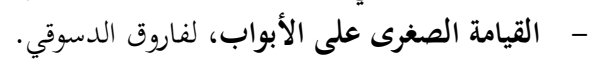

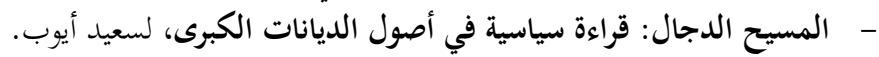

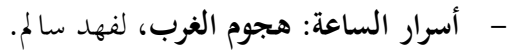

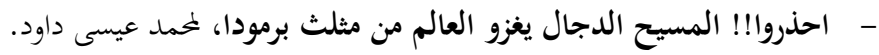

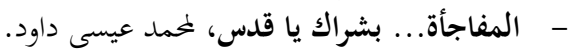

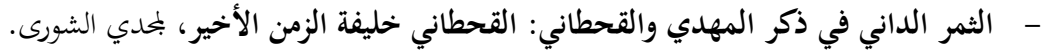

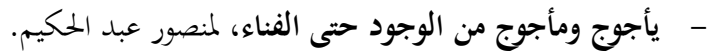
- - عشرة ينترها العالم، لمنصور عبد الحكيم. 
لذا تتنـاول هـذه الدراسة الإشكالية الناجمة عن الأخطاء التي تغصّ بهـا الكثير مـن

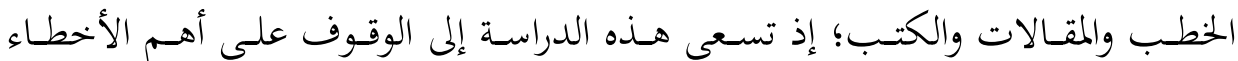

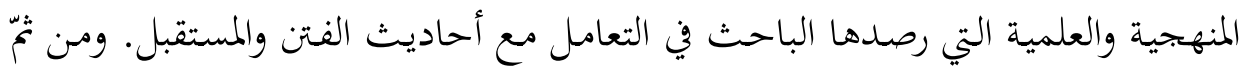

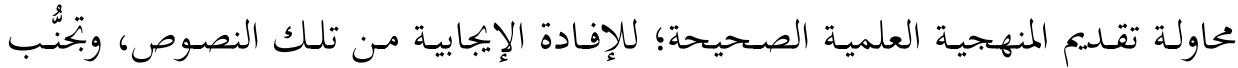
سلبيات التعامل الخطأ.

وقد وقفنا على بعض الدراسات والمؤلَّفات التي تتصل بموضوع الدراسة، وسنبيِّن فيما يأي أسماءها وصلتها بالدراسة: - القواعـد والضـوابط في فهـم أحاديـث الفـتن، وأشـراط السـاعة، دراسـة عقديـة مقارنة، للباحثث: خالد بن محمـد بن سالم العبدلي، رسالة ماجستير مقدمة لجامعة آل

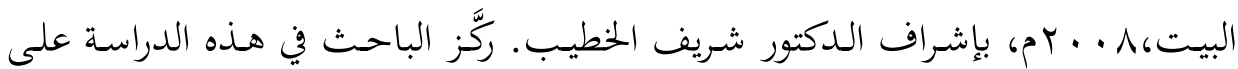

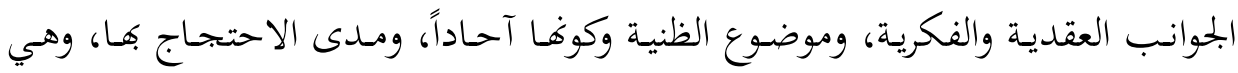
مفيدة في بابها.

- استشراف المستقبل في ضوء الحديث النبوي الشريف: محمد بشار الفيضي.؟ - استشراف المستقبل في ضوء السنة النبوية: عبد الرحمن قشوع. وهـذان البحثـان يتنـاولان حـديث النبي عـن المستقبل، وكيف نفيـد منـه في حاضـرنا ومستقبلنا، وهما مفيدان في بابهما.

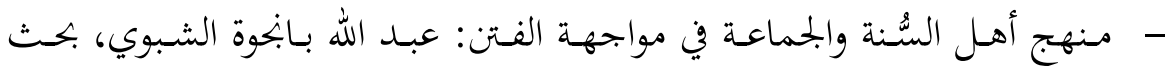

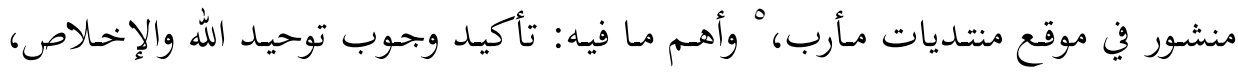

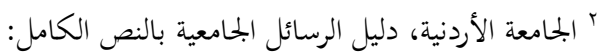
- https://theses.ju.edu.jo/Show_Abstract.aspx?par1=JUA0666150?Page=2. r بمعية الحديث الشريف، دليل الأبحاث المحكمة والرسائل الجامعية

- http://www.hadith-turath.org/researches. "جمعية الحديث الشريف، دليل الأبحاث المحكمة:

- http://www.hadith-turath.org/researches.

- http://mareb.org/showthread.php?t=10488.

$$
\text { • موقع منتديات مأرب: }
$$


والتوبـة والعبـادة، والاعتصـام بالكتـاب والسُّـنة، والالتفـاف حسول العلمـاء، ولزووم جماعـة

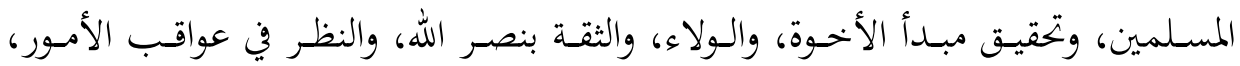

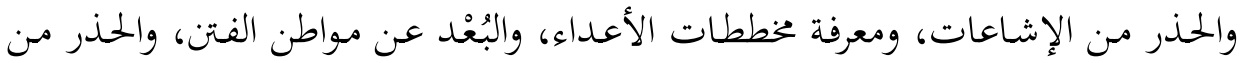

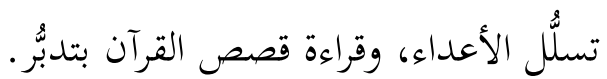
- معا لم ومنـارات في تنزيل أحاديـث الفتن والملاحسم وأشـراط السـاعة على الوقائع

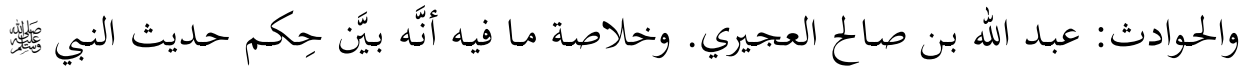

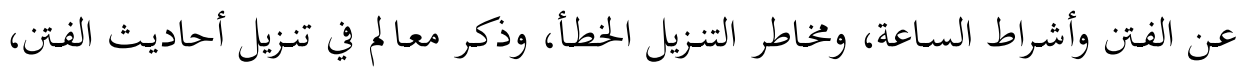

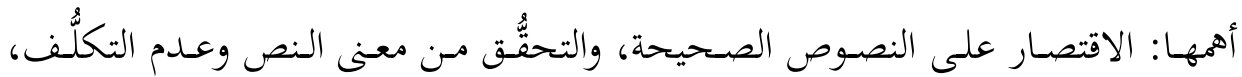
والرجوع إلى العلماء، والتحقُق من الواقعة، وعدم محاكمة نصوص المستقبل للواقع. - الضـوابط الشـرعية لموقف المسـلم مسن الفـتن: الشـيخ صـالح بـن عبـد العزيز آل

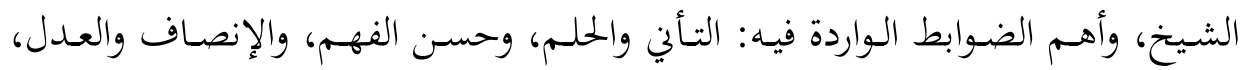
ووزن الأمور بميزان الشرع، ومخاطبة الناس بما يعقلون، والموالاة للمؤمنين. v

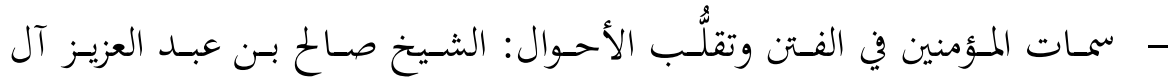

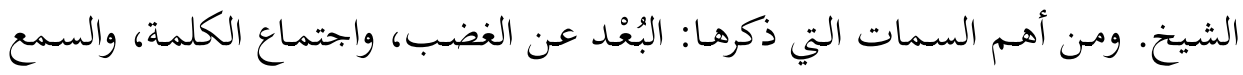
والطاعة لولاة الأمر، والرجوع إلى العلماء، وعدم الركون إلى الإعلام المغرض. ^

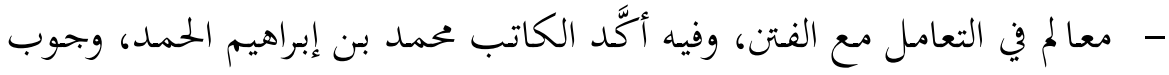

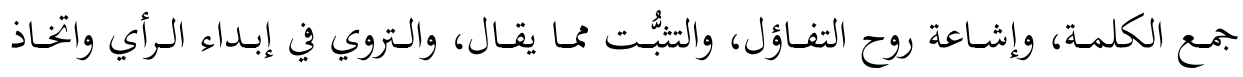
الموقـف، والبُعْد عـن مـواطن الفـتن، وترسـيخ الفهـم الصـحيح للقـدر، ومراعـاة المصـالح والمفاسد.

- http://www.dorar.net/article/54

$$
\text { ' كتاب منشور في موقع الدرر السنية الإلكتروني: }
$$

- http://islamhouse.com/ar/books/468612/

$$
\text { نص محاضرة منشورة في الموقع الإلكتروني لبيت الإسلام: }
$$

- http://subulsalam.com/play.php?catsmktba=13006

$$
\text { ^ نص محاضرة منشورة في الموقع الإلكتروني لسبل السلام: }
$$

9 كتاب منشور في الموقع الإلكتروني لبيت الإسلام:

- http://islamhouse.com/ar/books/172584. 
- - مبيل النجاة من الفتن، للباحث مصطفى العدوي، وهذا البحث لم يخرج عمَّا ذذكِر. 1.

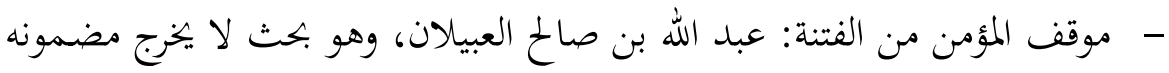
عمَّا ذُكِر آنفاً. '

بعد الاطلاع على تلكم البحوث لاحظنا أَََّّا تتحدَّث عن الموقف من الفتن إجمالاً،

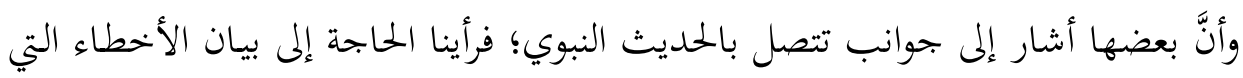

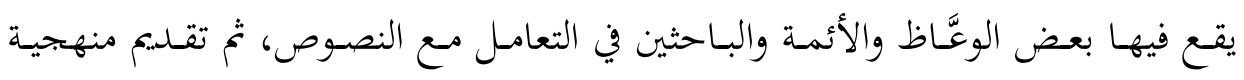
متكاملة فيها. وقد جاء البحث في ثلاثة مطالب وخاتمة: - المطلب الأول: التعريف بالمصطلحات ذات الصلة، وِكم ورود أحاديث الفتن. - المطلب الثاني: أخطاء وسقطات في التعامل مع أحاديث الفتن والمستقبل. - المطلـب الثالـث: قواعـــ وضـوابط في منهجيـة التعامـل مـع أحاديـث الفـتن والمستقبل.

أولاً: التعريف بالمصطلحات ذات الصلة، وِكم ورود أحاديث الفتن

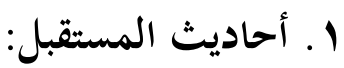

تـرد أحاديـث المسـتقبل في السُسـنة ضـمن أبـواب أشـــاط السـاعة، وأبـواب الفـتن

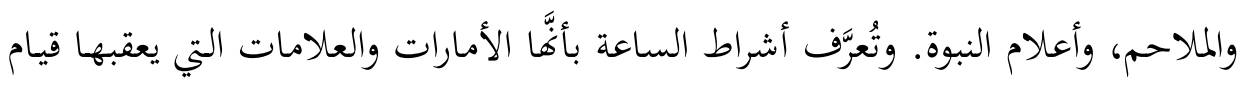

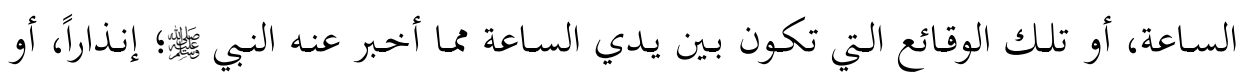
'ب بحث منشور في الموقع الإلكتوري لكاتبه مصطفى العدوي: - http://mostafaaladwy.com/play-8111.html.

" بحث منشور في الموقع الإلكتووني لصيد الفوائد، والمكتبة الشاملة: - http://www.saaid.net/book/open.php?cat=82\&book=979. 


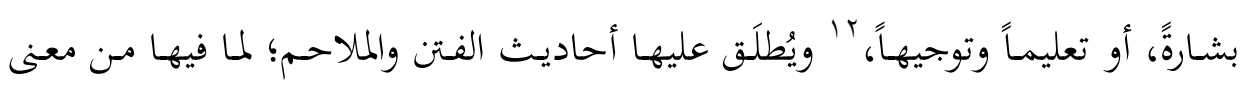
الاختبار والابتلاء والتمحيص.

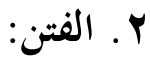

الفتنة لغةً: أصلٌٌ يدلُّ على ابتلاء واختبار. بَ أمَّا اصطلاحاً فتُطلَق على: ما يتبيَّن به

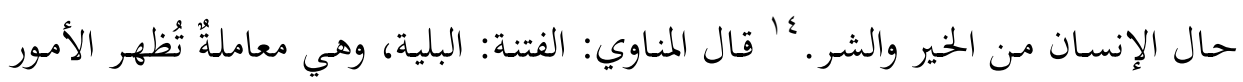
الباطنة.

وتُعرَّف الفتنة أيضاً بأَََّا الامتحان أو الاختبار المُذذِبب للعقل أو المال، أو المُضِل عن الحق. 17

وأخطر الفـتن نوعـان: فتنـة الشبهات، وهي أعظم الفتنتـين، وفتنـة الشهوات، وقـد

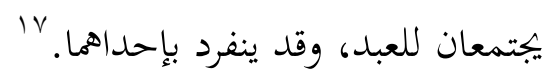

rا ابن الأثير، بحد الدين المبارك بن محمد الجزري. النهاية في غريب الحديث، بيروت: المكتبة العلمية، د.ت، ج؟، صب آع. انظر أيضاً: - ابن حجر، أحمد بن علي العسقلاني. فتح الباري شرح صحيح البخاري، بيروت: دار المعرفة، د.ت، ج؟ 1، - حوّى، محمد سعيد. الأساس في السُّنة وفقهها: العقائد الإسلامية، القاهرة: دار السلام، طس، 999 1م، - حوَّ.

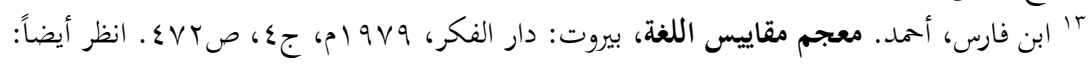

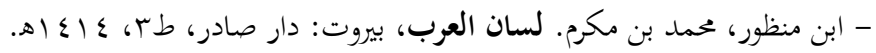

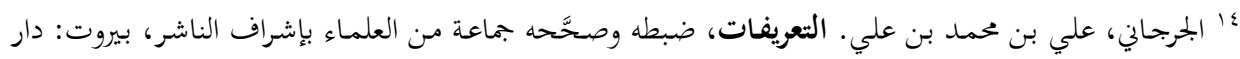

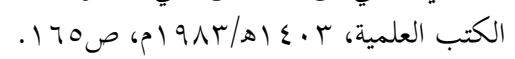

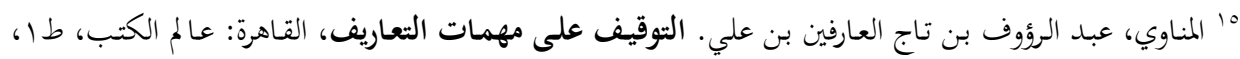
. ror.

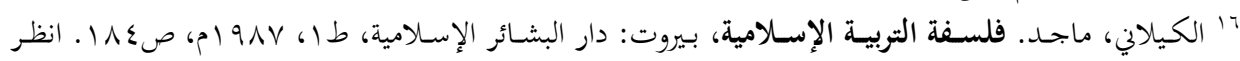

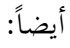

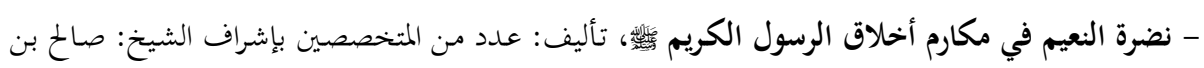

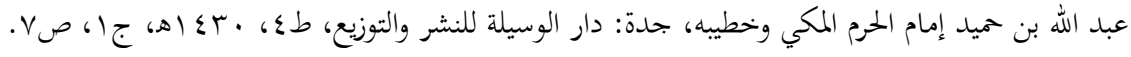

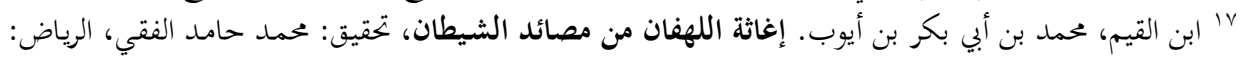

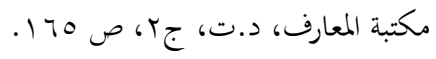


وتأسيساً على ما سبق، يُطلَق مصطلح "الفتن والملاحمث" على معنى خاصِّ، ويُقصَد

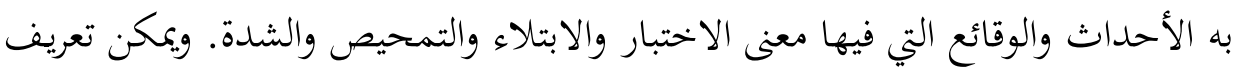

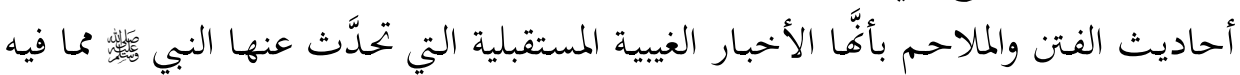
ابتلاء وشدة، أو أحداث عظام؛ تحذيراً، أو توجيهاً وإرشاداً.

\section{r. رِكم ذكر أحاديث الفتن وأشراط الساعة:}

أ. بيان بعض مـا سيكون بين يـدي الساعة مما تتزلزل له القلوب، وفيه مـن الهول

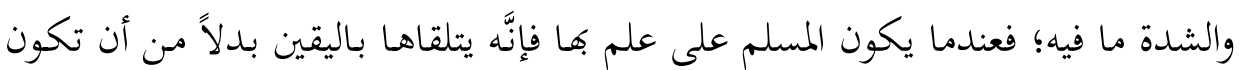
سبباً لزعزعة هذا اليقين.

ب. الإخبار ببعض ما سيحدث يُعِدُّ المسلمَ للتعامل مع هذه الأحداث بما يناسبها؛ سواء من ناحية أحكام الفقه، أو من جهة الفهم؛ لئلا تكون سبباً في فتنة أو الخراف. ت. كشف هذه الأخبـار عن كثير مـن الدعوات الكافرة والفرق الضـالة بمـا يحصِّن المسلم من أن يقع في أحابيلها.

ث. تعرُّف النصوص الصحيحة في هذا الباب يُعمِّق لدى المسلم الأملـ؛ لئلا يقع في اليأس؛ إذ يبيِّن بحمل هذه الأحاديث أنَّ هذه الوقائع متغيرة غير ثابتة ولا مستقرة، فضالًا عن بيان سبل مواجهتها.

$$
\begin{aligned}
& \text { 11 ألّف في هذا الموضوع مؤلّفات عدَّة، أهمها: } \\
& \text { - الفتن والملاحم، المروزي، لأبي عبد الله نعيم بن حمادة الثماد. }
\end{aligned}
$$

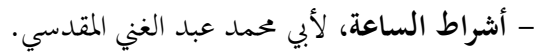

$$
\begin{aligned}
& \text { - النهاية في الفتن والملاحم، لابن كثير الدئ الدمشقي. }
\end{aligned}
$$

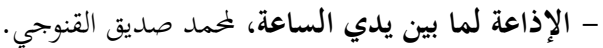

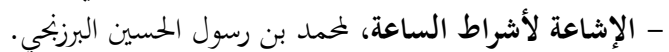

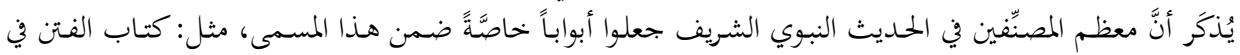

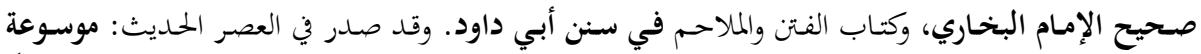

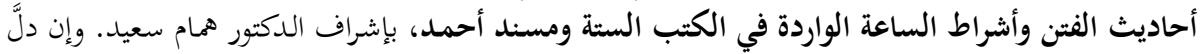

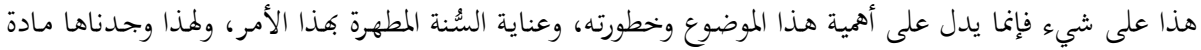

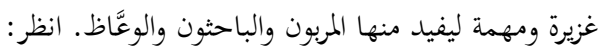

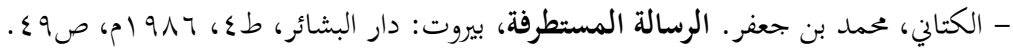

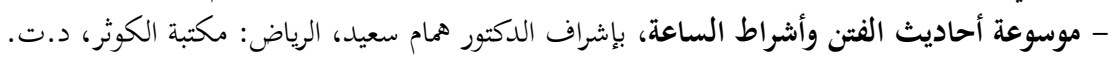


19

$$
\text { ج· بيان بعض معجزات النبوة في الإخبار عن غيب سيقع. }
$$

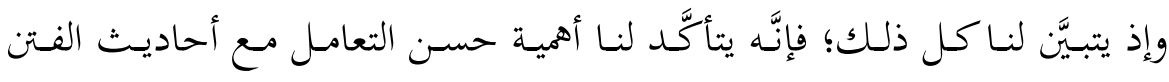

$$
\text { والمالاحم والمستقبل. }
$$

\section{ثانياً: أخطاء وسقطات في التعامل مع أحاديث الفتن والمستقبل}

لا شــكَّ في أنَّ كثـيراً مـن البـاحثين والدارســنـ وأهـل العلـم وطلبتـهـ والـدعاة هــم

أصسحاب درايـةٍ وفقـهِ راقٍ في التعامـل مـع أحاديـث الفـتن والمسـتقبل، بكيـث ينتقـون منهـا

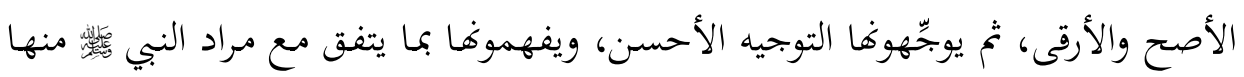
قدر الجههد البشري، ويكسنون تنزيلها على الوقائع، ويعملون بما للديهم من قدرة علمية وحصيلة معرفية على رفع ما قد يرد في بعضها من إشكالات، فضالًا عن حسن اختيار، بما يتفق مـع الواقع والعصر أو المخاطب، وهـا لا يمكن حصره. وبـالرغم مـن ذلك فإنَّه توجد بعض الزلات والأخطاء التي يقع فيها بعض طلبة العلم أو الدعاة والوعَّاظ، فضالًا عن عامَّة الناس، في تعاملهم مع أحاديـث الفتن، التي لمستُها عملياً من سماعي لبعضها؛ سـواء على منـابر الجمعـة، أو دروس المسـاجد، أو مـا يلقى في الفضـائيات الإسـالامية،

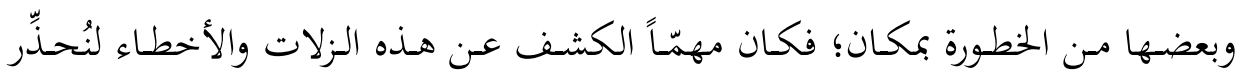
منها، ونصل بعد ذلك إلى المنهج الأصوب في هذه القضية. وفيما يأتي بيان لأهـم هذه الأخطاء:

\section{ا ـ الاعتماد على النصوص الضعيفة أو الموضوعة:}

لا شـاكَّ في أنَّ هـذا الأمسر هـو مـن أخطـر مـا يقـع فيـه بعض البـاحثين والخطبـاء والوعَّاظ، ولعل مردّ ذلك الأسباب الآتية:

أ. افتقار بعضهم إلى القدرة على تمييز الصحيح من السقيم، وعدم الرجوع إلى أهل

التخصص في ذلك. 
ب. اعتماد بعضهم على كتب لا تلتزم الصحة، وعدم مراجعة أحاديث هذه الكتب في المصادر المعتمدة التي تُعِين على تمييزها.

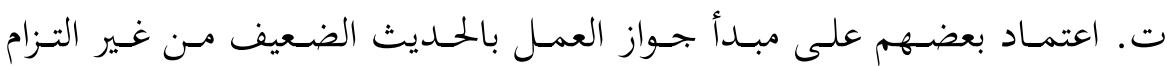
بالشروط والضوابط الدقيقة التي وضعها علماؤنا للتعامل مع الحديث الضعيف.

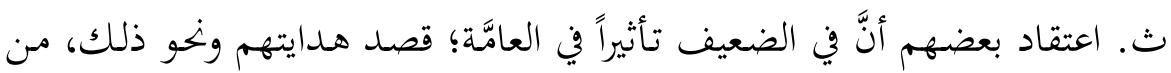

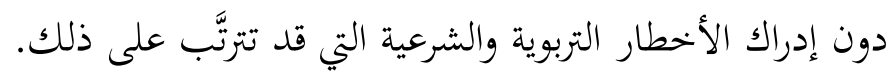

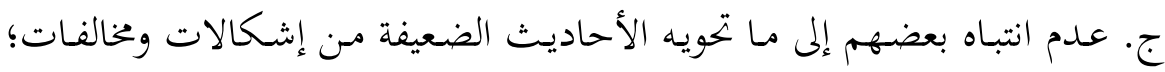

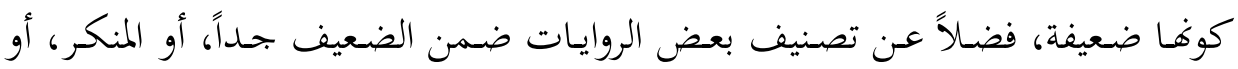
الموضـوع، ثم استشـهادهم بهـا -بـالرغم مسن ذلكـ- بوصـفها تـدور في فلـك الضعيف،

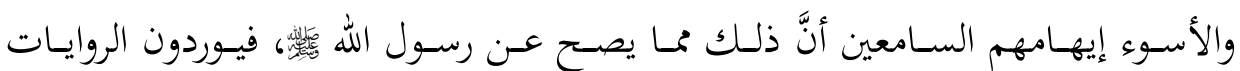
الموضوعة، أو المشكلة، أو المخالفة شرعاً.

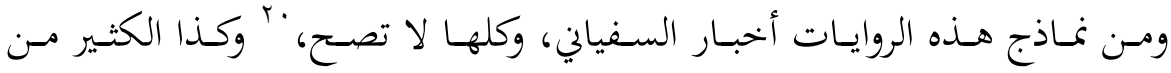

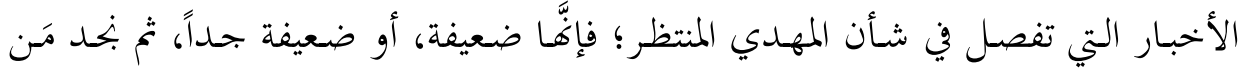

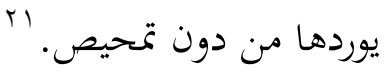

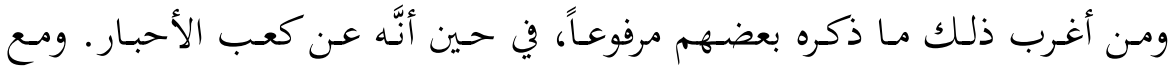

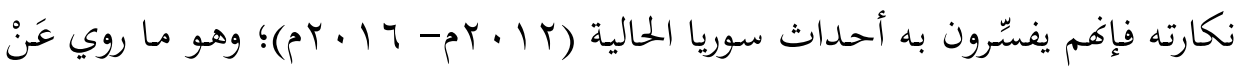

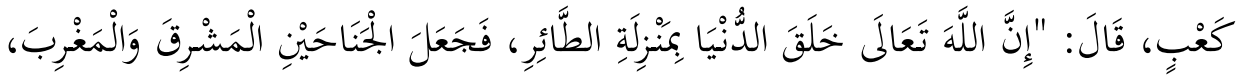

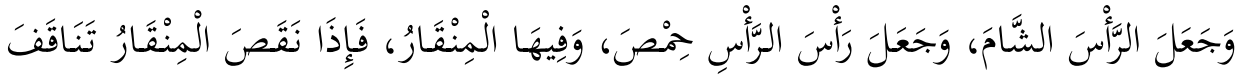

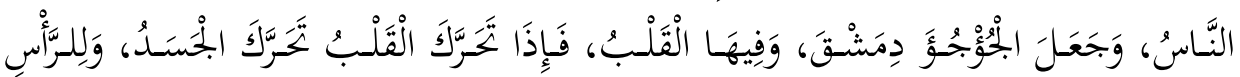

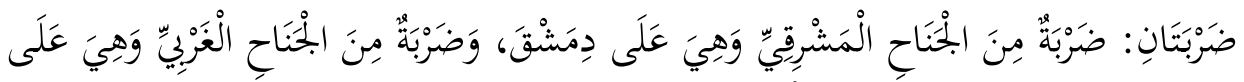

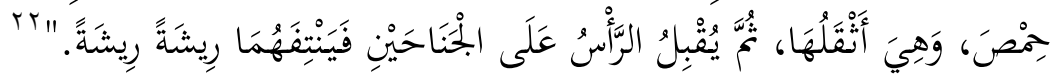

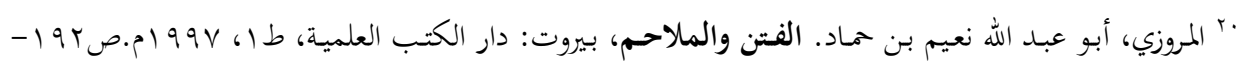
( )

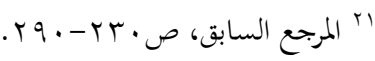

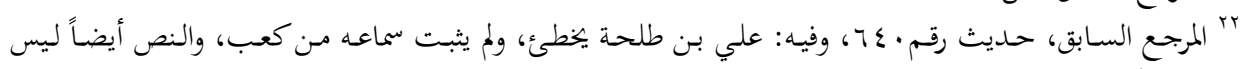


ونظراً إلى خطورة هذه الروايات على الاعتقاد والعمل، فضلاً عن نسبة ما لا يثبت إنس إلى نبينا بَّ

\section{Y. . عدم تحري الصحة في الأحاديث:}

وذلك بأن تروى أحاديث يُعتقد بصحتها، وهي لا تصح، مثل حديث عبد الله بن

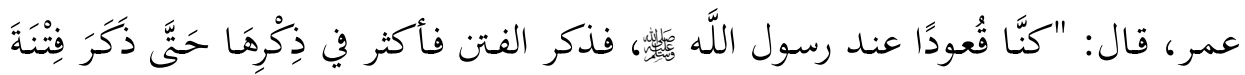

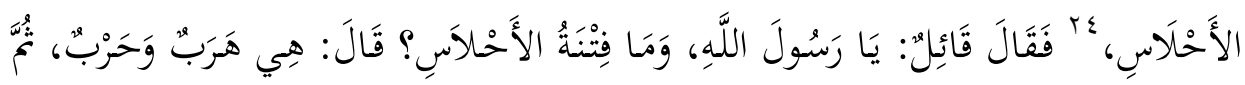

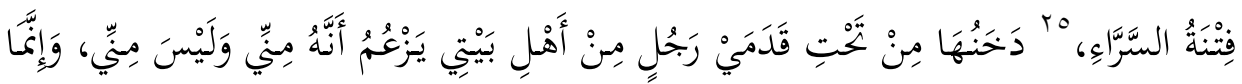

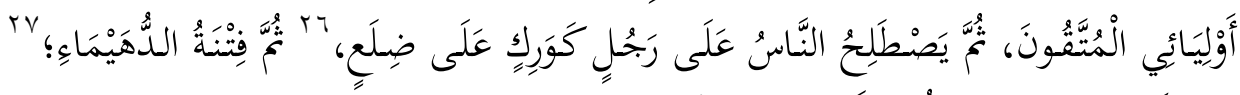

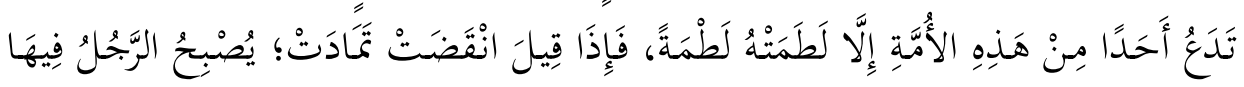

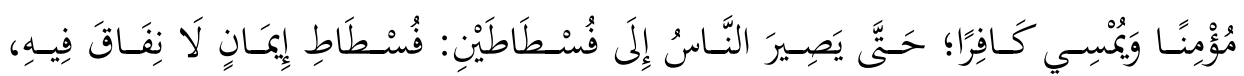

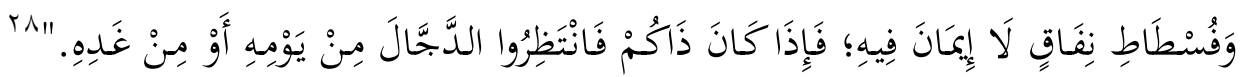

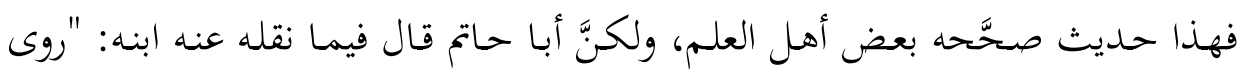

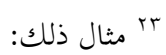

- ابن الجوزي، عبد الرممن بن علي. الموضوعات، المدينة المنورة، المكتبة السلفية، د.ت.

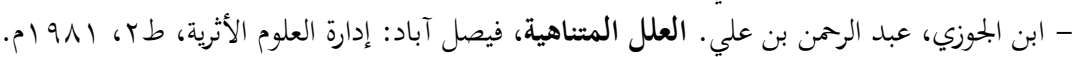

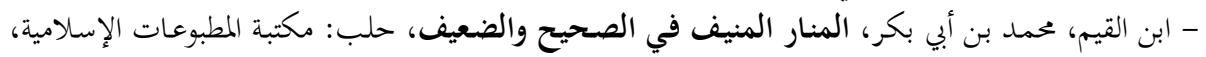

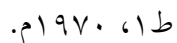

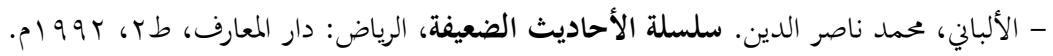

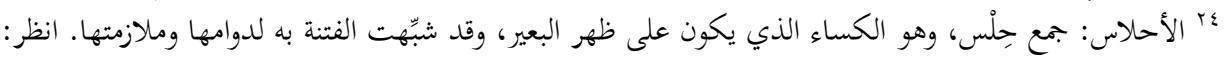

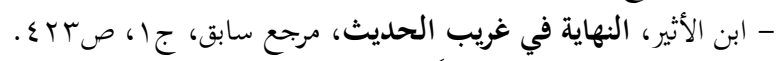

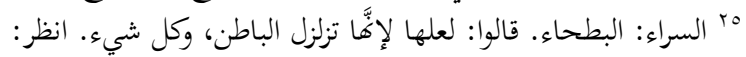

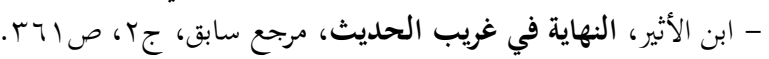

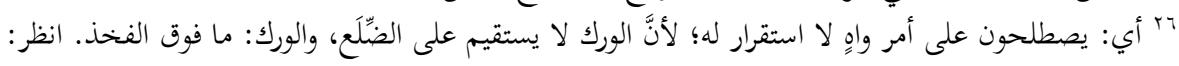

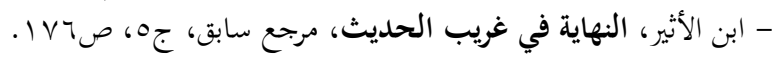

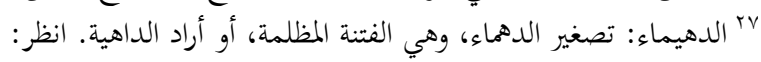

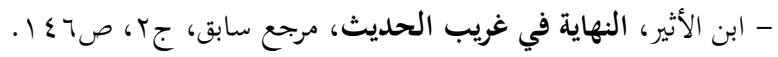

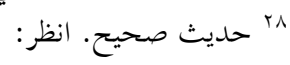

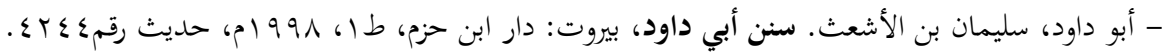

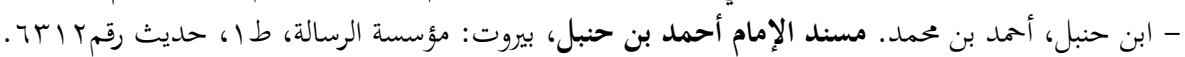


هذا الحديث ابن جابر، عن عمير بن هانئ، عن النبي

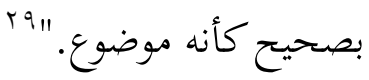

\section{r. التساهل في إطلاق الأحكام النقدية على النصوص:}

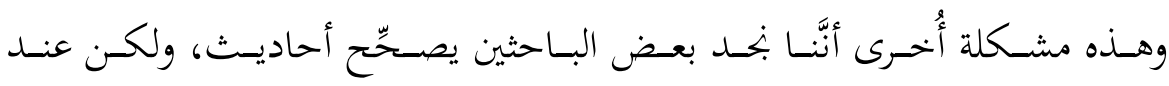

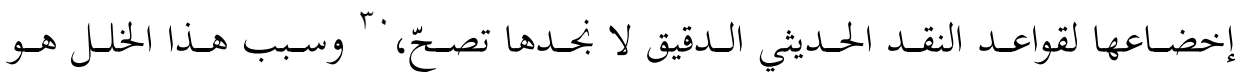
التساهل في تطبيق القواعد النقدية، ولعل من أمثلة ذلك حديث: "خذوا العطاء مـا دام

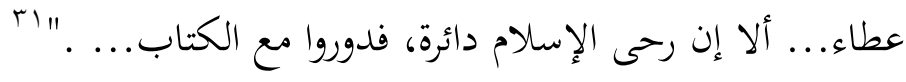

\section{ع ـ الاستشهاد بالإسرائيليات:}

الإسـرائيليات: جمـع إسـرائيلية، نسـبةً إلى بـني إسـرائيل. وإسـرائيل هـو يعقـوب بـن إسحاق بن إبراهيم الخليل عليهم السلام، ومَن تناسل منهم إلى عهد موسى اليَليَلة)، ومَن

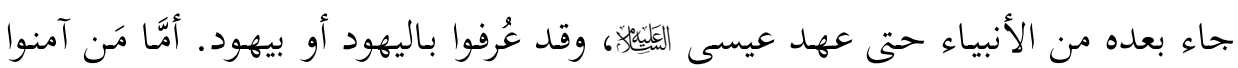

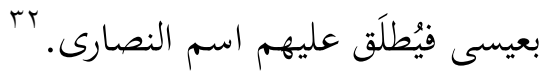

ولفظ "الإسرائيليات" وإن كان يدل بظاهره على اللون اليهودي للقصص والروايات من الأخبار، فإنَّ المراد بـه أوسع من ذلك وأشمل، فيعم اللون اليهودي واللون النصراين للتفسـير؛ إذ إنّ إطـلاق هـذا اللفـظ على جميـع ذلك هـو مـن بـاب التغليـب للجانـب اليهودي.

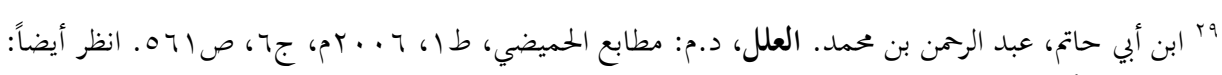

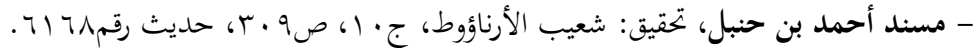

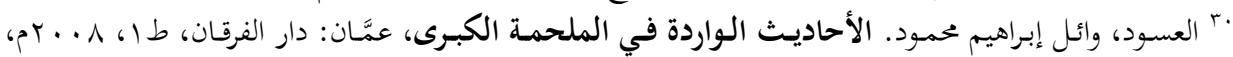

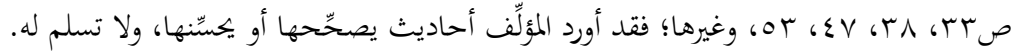

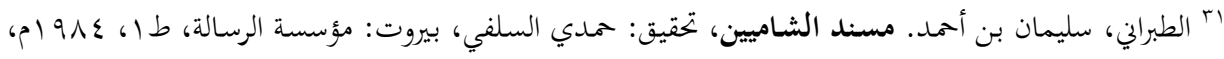

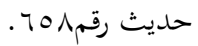

rr أبو شهبة، محمد بن محمد. الإسرائيليات والموضوعات في كتب التفسير، د.م: مكتبة السُنة، طع، م -ــ (هـ، 


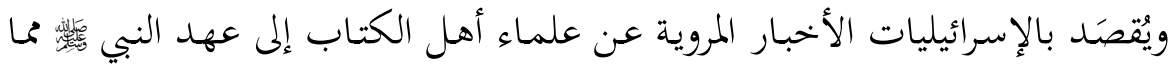

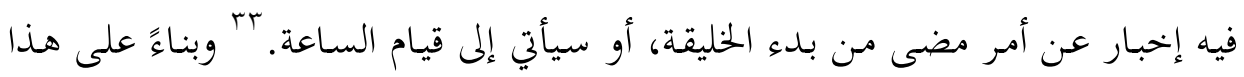

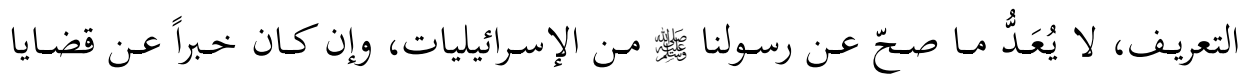

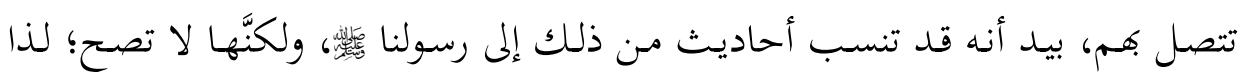
وجب التحرّي.

ونقلت بعض كتـب التفسير والروايـة شيئاً مـن هـذه الإسرائيليات، مـن دون تمييز

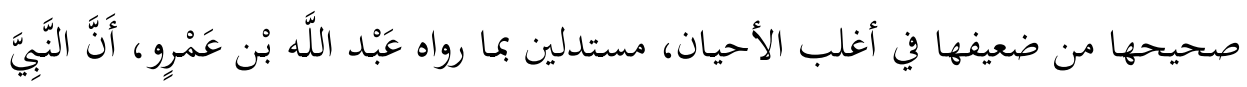

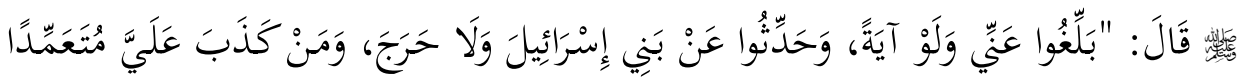

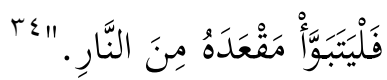

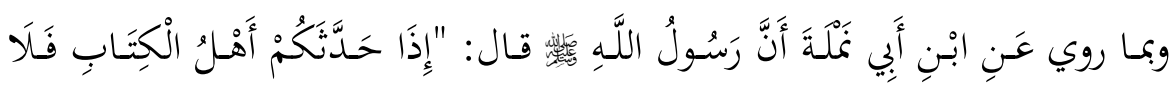

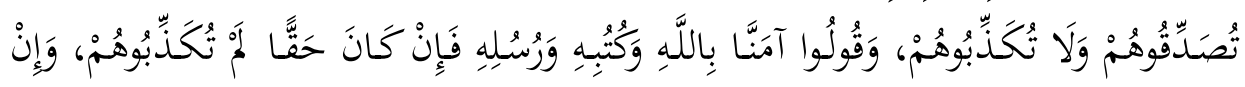

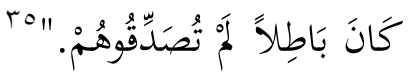

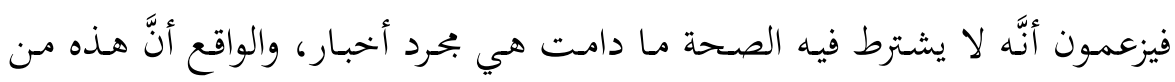

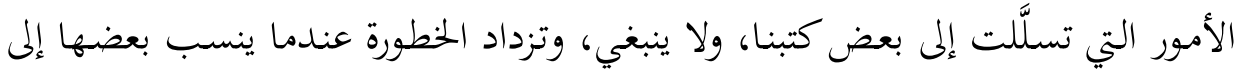

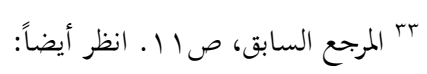

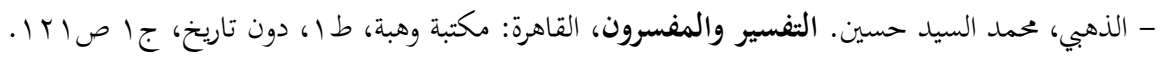

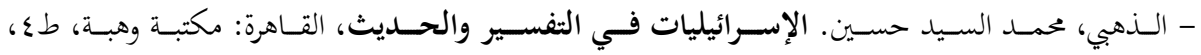

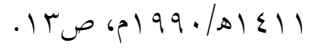

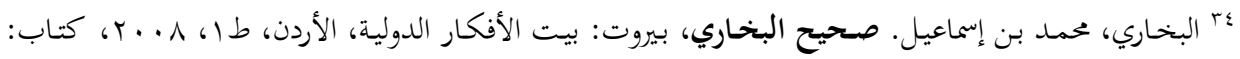

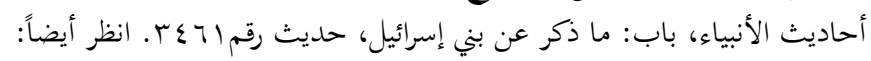

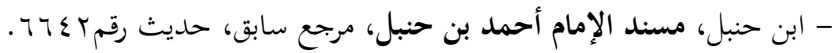

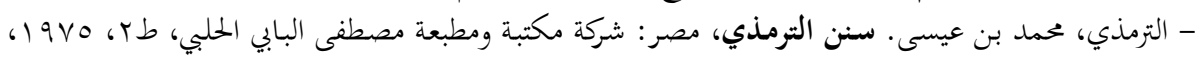

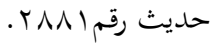

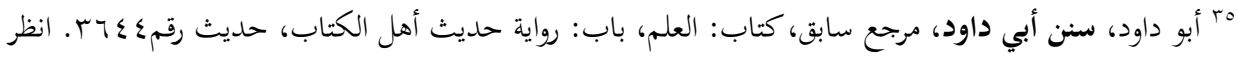

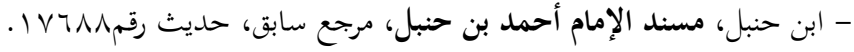

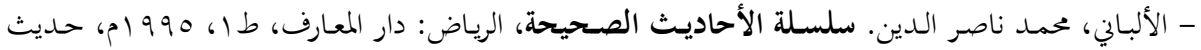


رسول الله

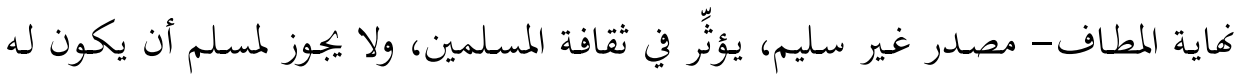

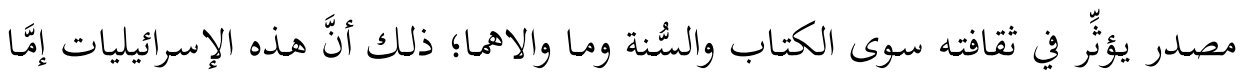

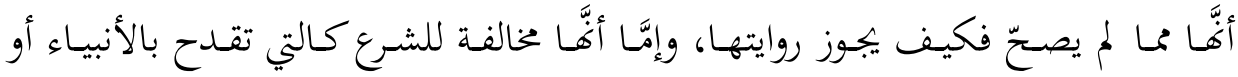

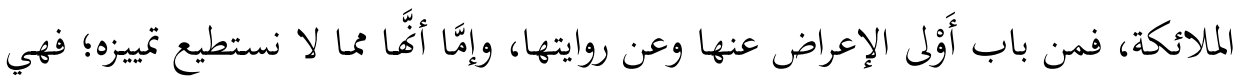

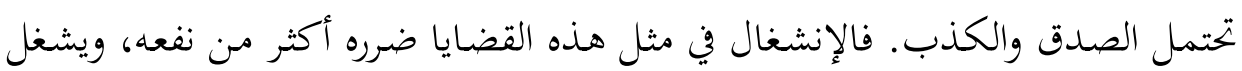

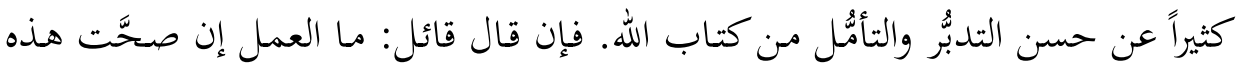

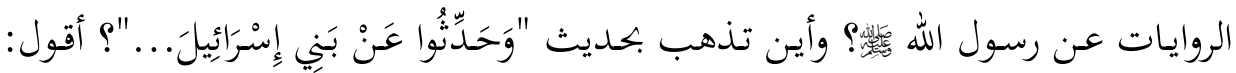

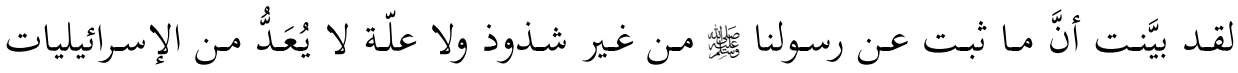

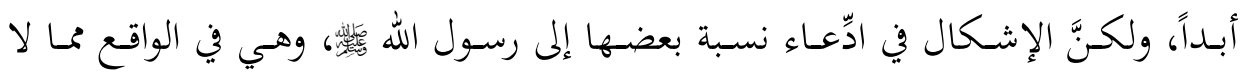

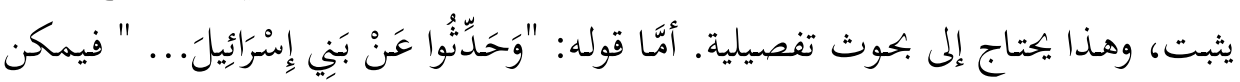

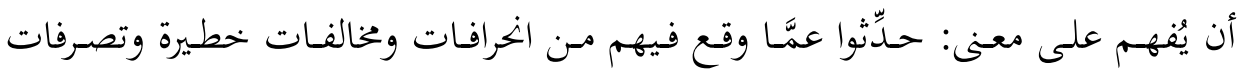

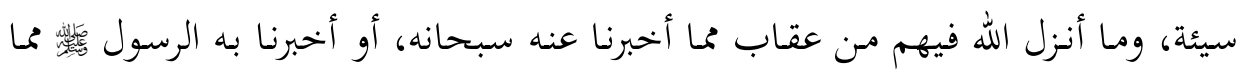

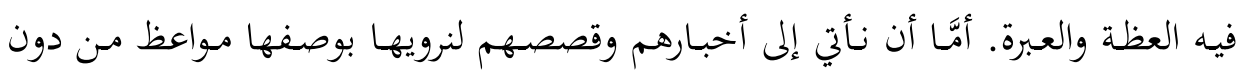

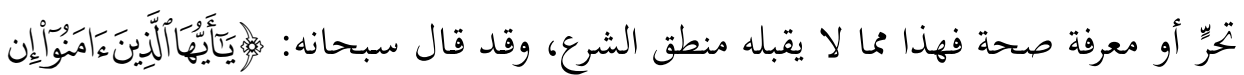

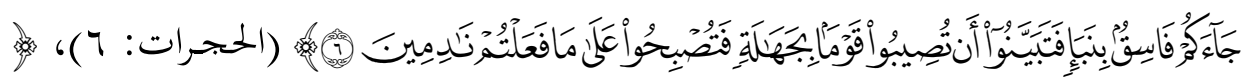

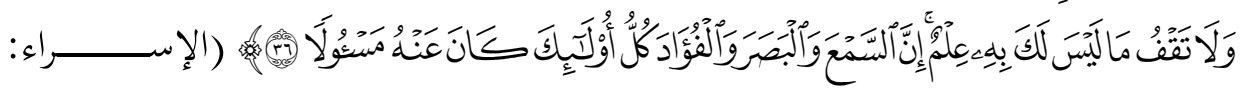
. (r)

وحسبك للتدليل على خطورة هذا الموضوع ما قد يوردونه في قصة هاروت وماروت،

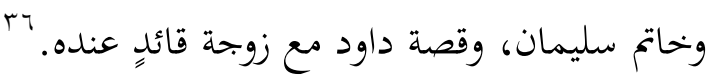

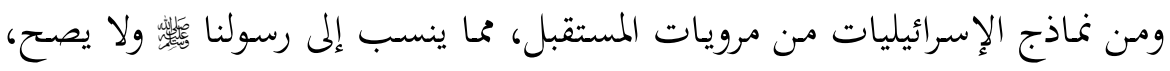

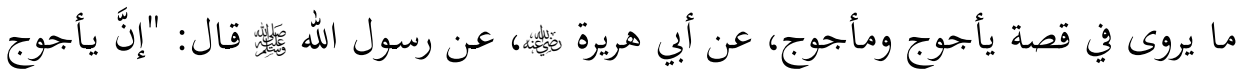

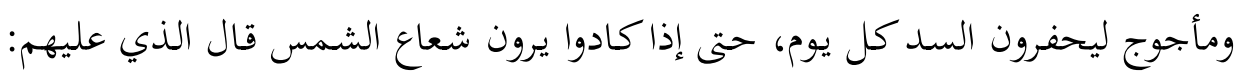

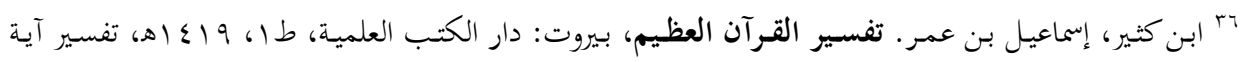

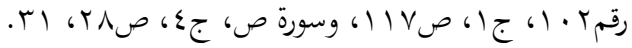


ارجعوا فستحفرونه غداً، فيعودون إليه كأشد ما كان، حتى إذا بلغت مدةقم، وأراد الله أن يبعثهم على الناس حفروا، حتى إذا كادوا يرون شعاع الشمس قال الذي عليهم: ارجعوا

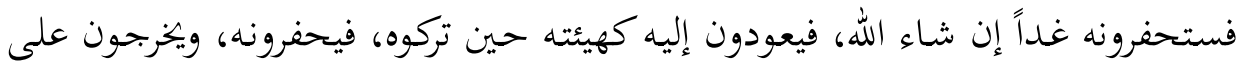

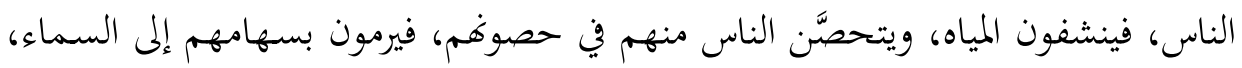

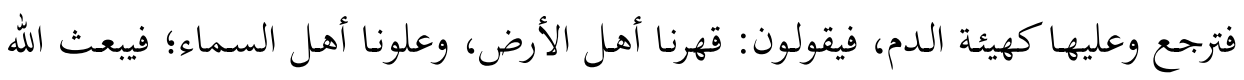

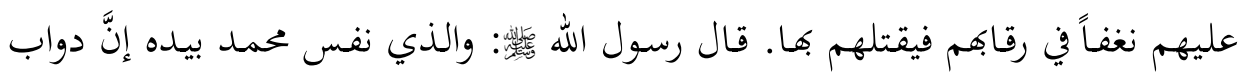

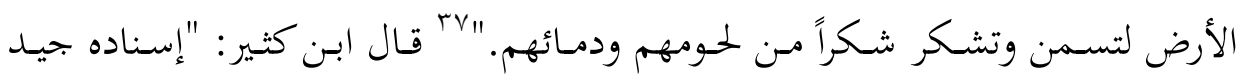

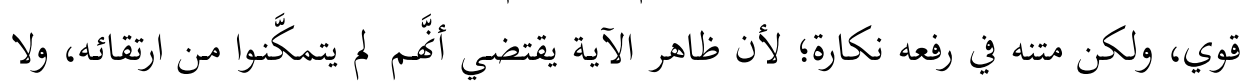

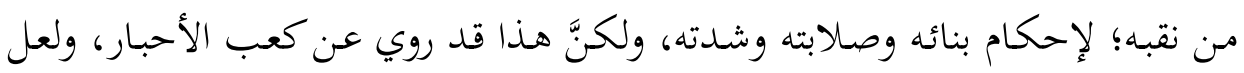

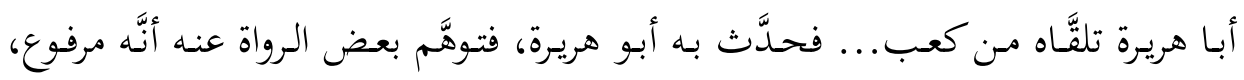

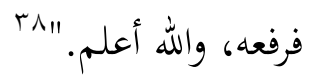

لا شـكَّ في أنَّ الإسـرائيليات تـدسُّ السُّم في الدســ؛ إذ قد ينطوي بعضـها على مـا

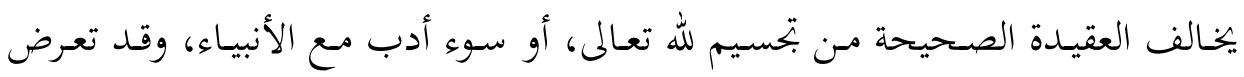

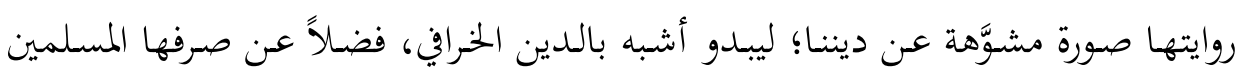

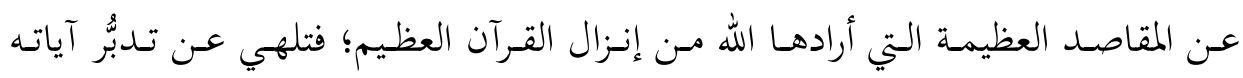

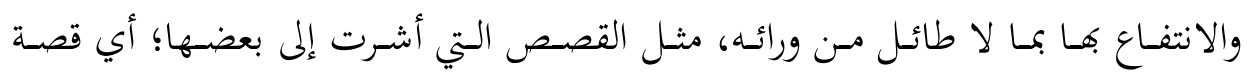
هاروت وماروت، والقصص المتعلقة بسليمان وداود عليهما السلام.

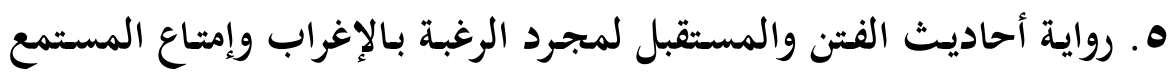
دون القدرة على الفهم الدقيق: - ملى

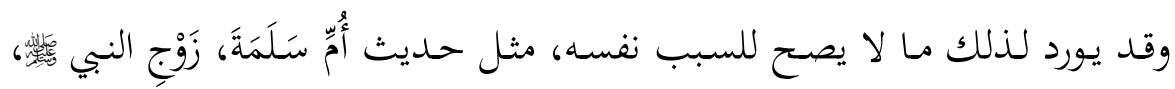
عَنِ النَّبِّ

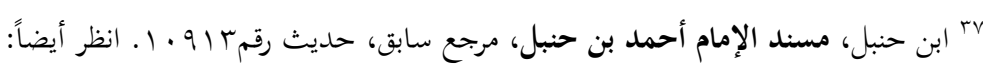

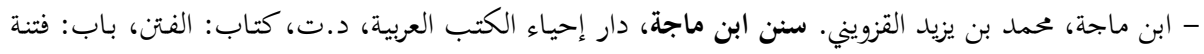

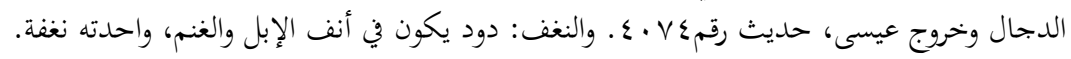

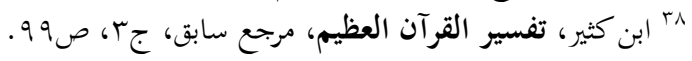




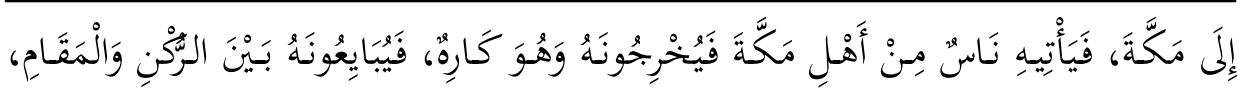

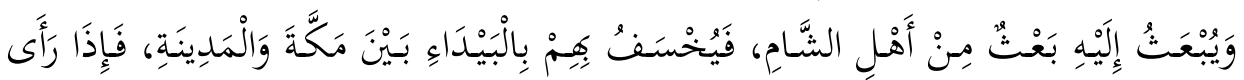

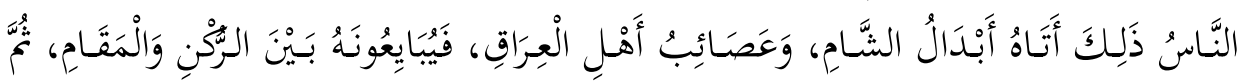

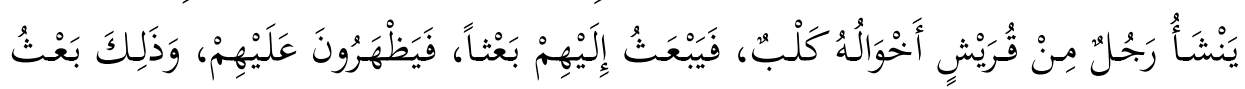

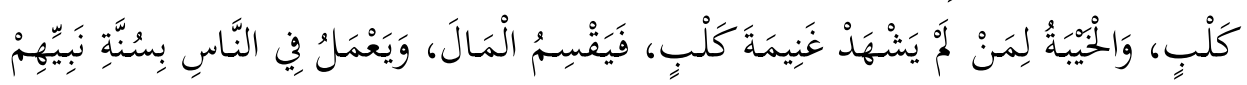

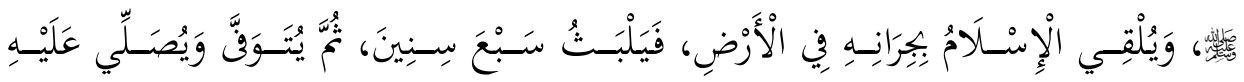

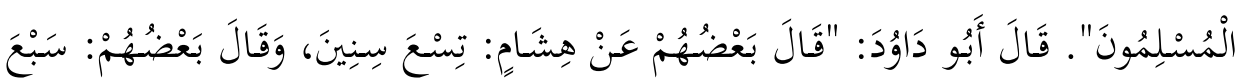
سِنِينَ.

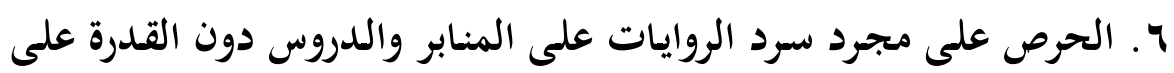
ربطها بالواقع، أو بيان حكمها وأحكامها، وكيف يستفاد منها في واقعنا: هذه المسألة هي من جملة ما قد يقع من خطأ، والأمثلة عليها كثيرة، ولعل ما سبق

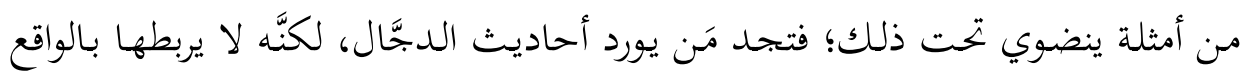

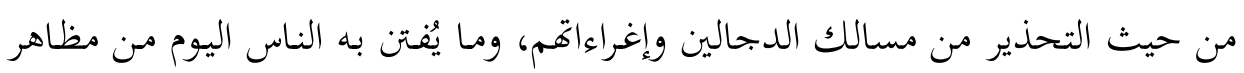
قوة العدو وإعلامهم وترغيبهم وترهيبهم.

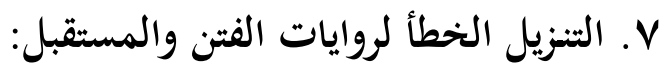

وهذا الأمر من أخطر ما قد يقع فيه بعض الدارسين وغيرهم؛؛ وذلك أنََّم يحرصون

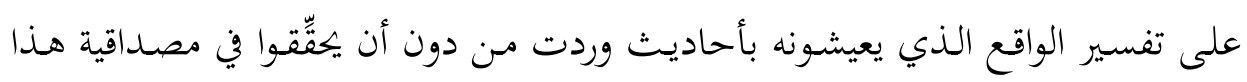

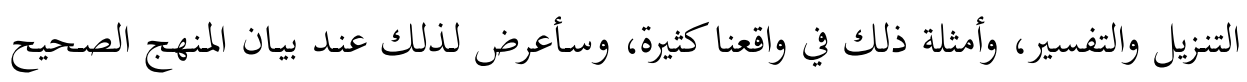
في هذا الأمر.

A. إيراد أحاديث الفتن والمستقبل بغرض التخدير والإقعاد عن العمل، وتعليق آمال المسلمين بالغيب؛ للتقاعس عن أداء الواجبات، وإحداث مفاسد كثيرة:

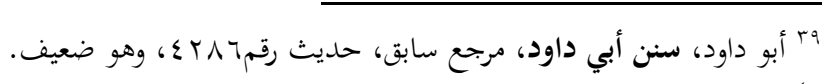

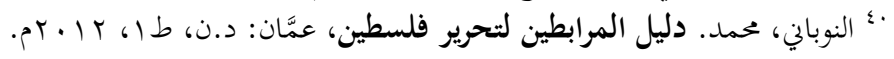


ولعل من أبلغ الأمثلة على ذلك الروايات الكثيرة التي يوردوها في شأن المهادي، وأنَّه

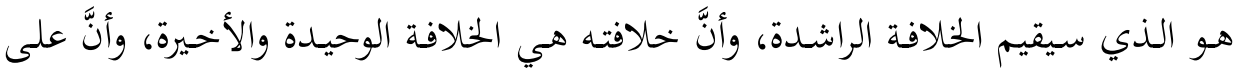

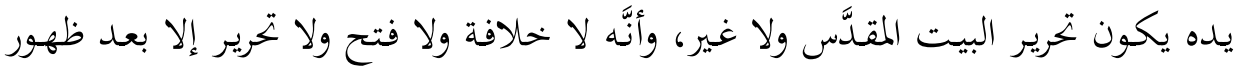

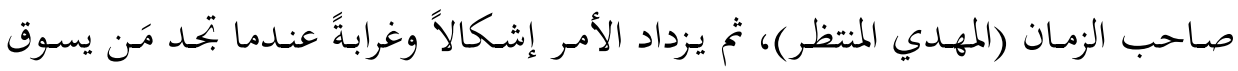

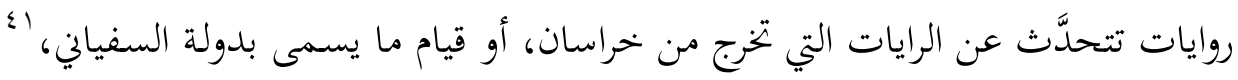

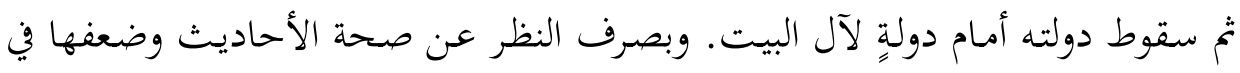

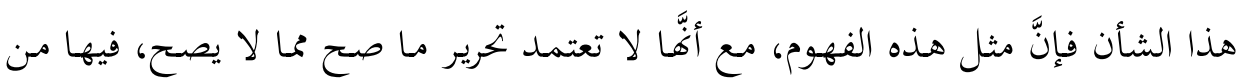

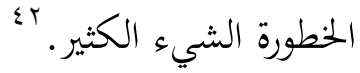

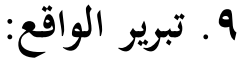

من الأخطاء التي قد يقع فيها بعضهم أنَّه في خضم رواية أحاديث الفتن والمستقبل

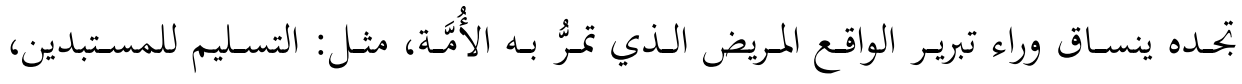

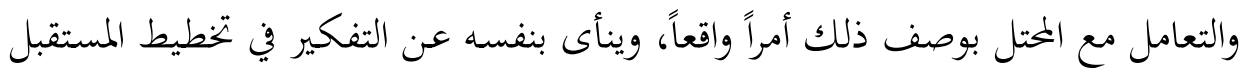

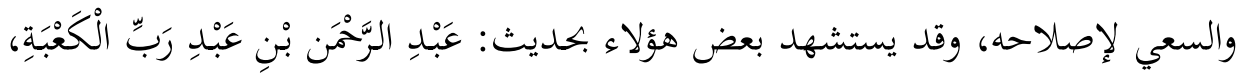

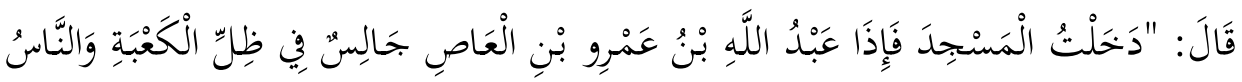

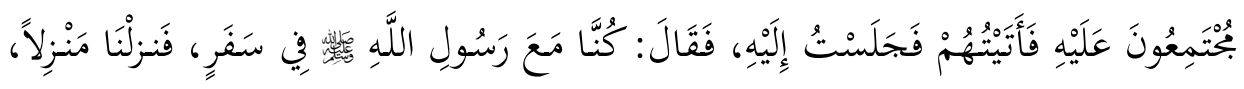

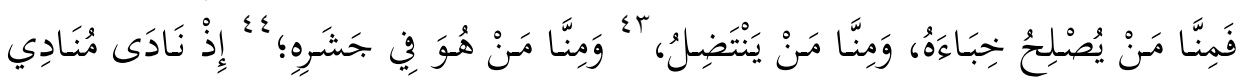

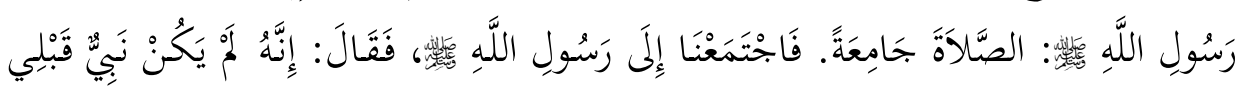

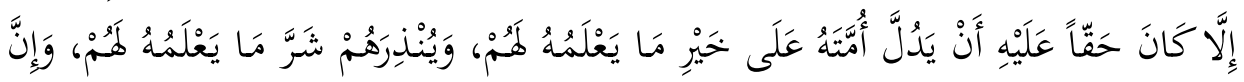

$$
\begin{aligned}
& \text { ا؛ لم يصح فيها شيء ألبتة. انظر رواياته في: }
\end{aligned}
$$

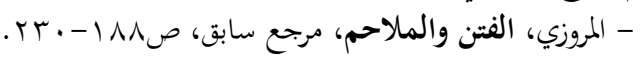

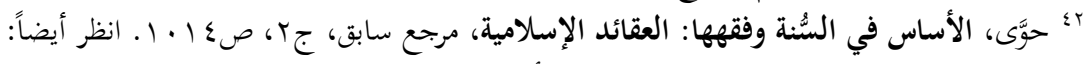

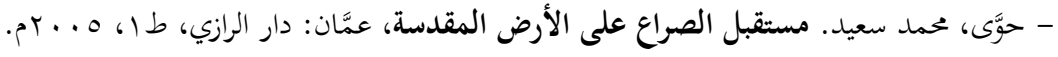

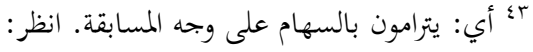

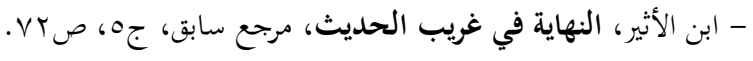

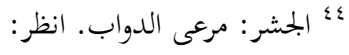

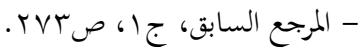




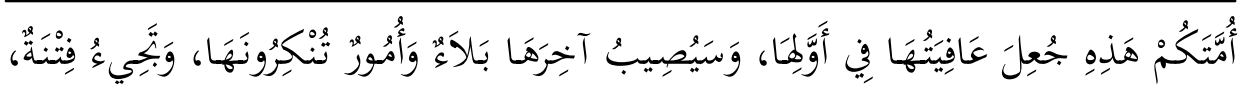

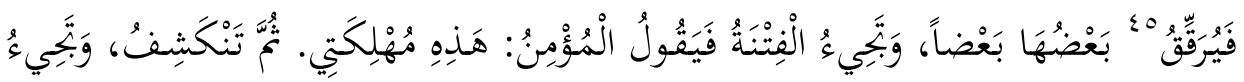

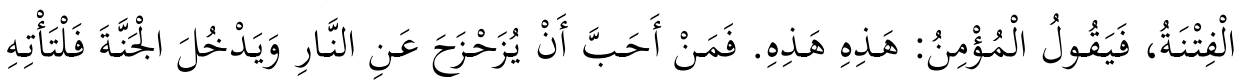

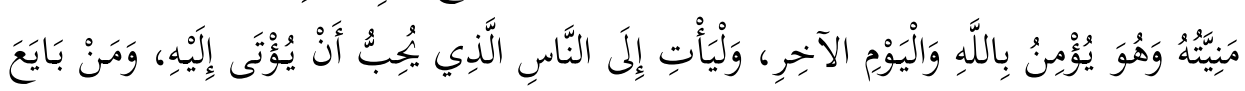

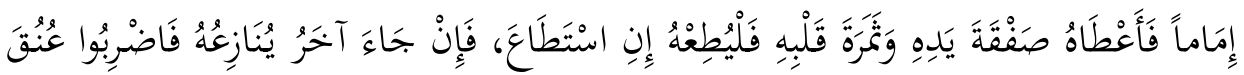
الآخَرِ....

إنَّنا بحاجة إلى فهم متكامل للنصوص؛ فإنَّ النصوص التي تأمر بطاعة أولياء الأمور

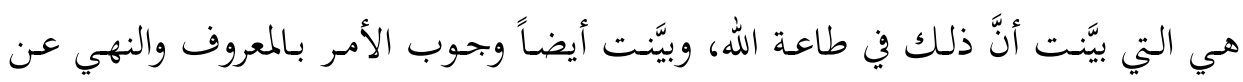
المنكر.

\section{• 1 ـ المبالغـة في تضـخيم الأحسداث والتهويل، وتحميل النص مـا لا يحتمل، على فرض صحته:}

اعتاد بعض الدعاة أو الوعَّاظ المبالغة في الترهيب والترغيب، مما قد يؤدي إلى إيراد

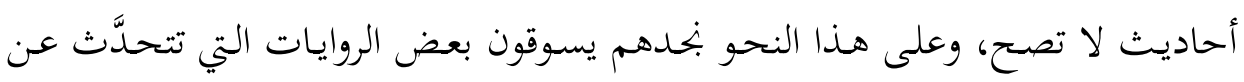

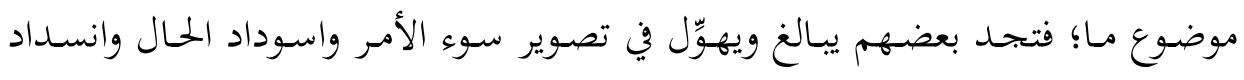

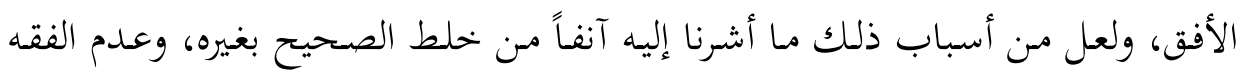

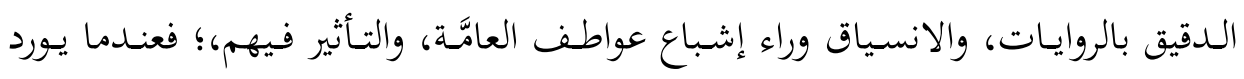

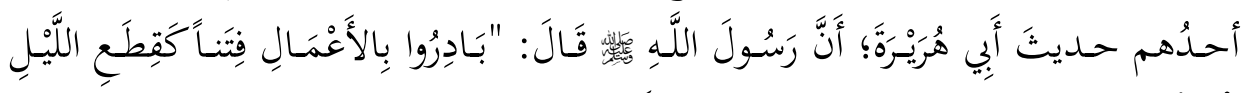

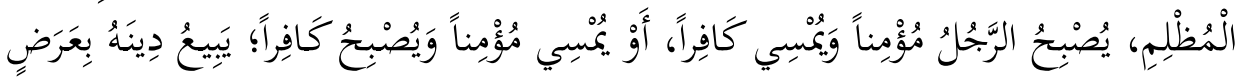

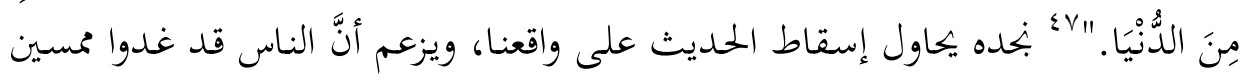

0 أي: يمهد ويشوق للفتنة التالية ويحسّنها. انظر:

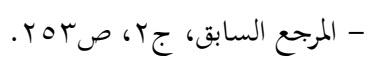

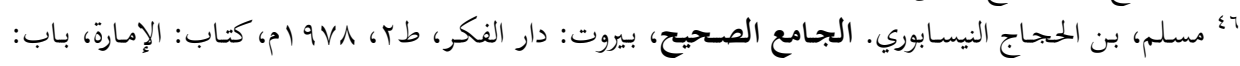

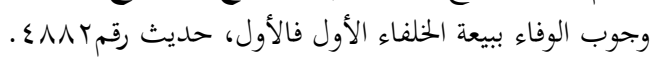

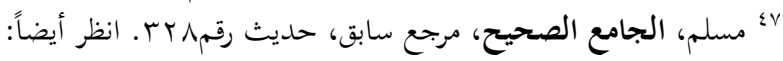

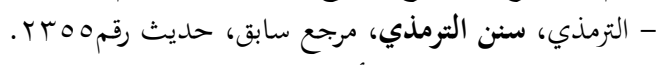

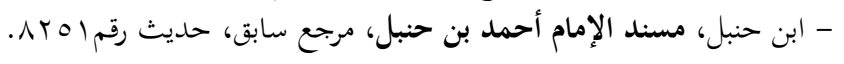




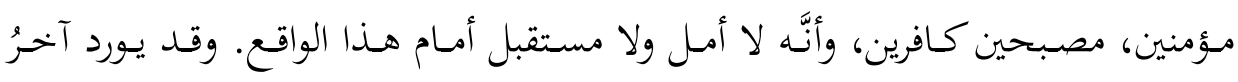

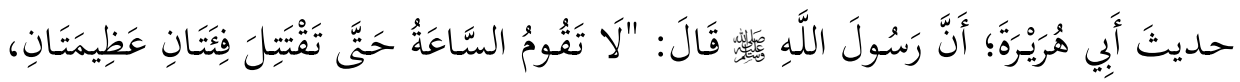

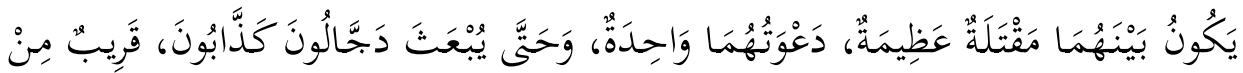

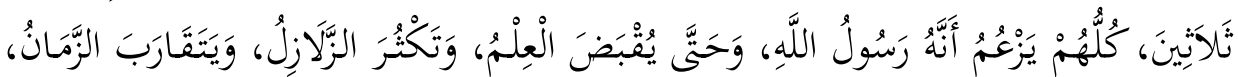

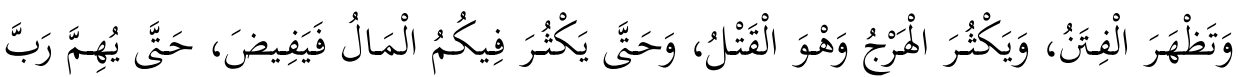

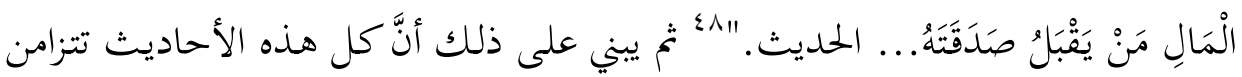

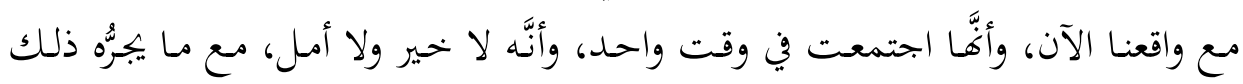

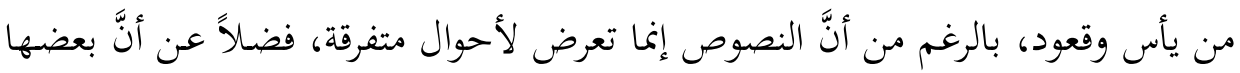
ربما يكون في آخر الزمان وليس الآن.

\section{ا I ـ إصدار أحكام خاطئة في حق الخلق:}

إنَّ عـدم التـدقيق في صحة الحـديث (سنداً، ومتنـاً)، ثم عـدم التدقيق في ألفاظه التي

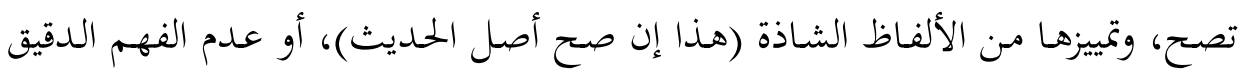

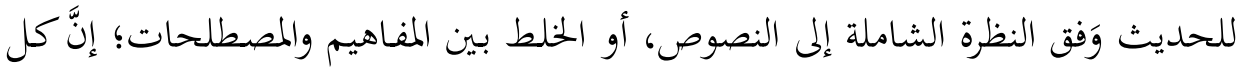
ذلك يتتَّب عليه إصدار أحكام غير صحيحة في حق الناس، ولعل أبرز مثال على ذلك

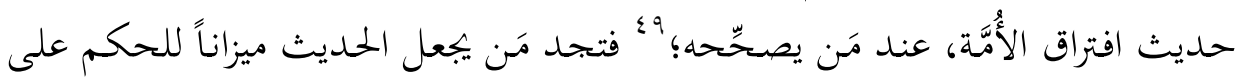

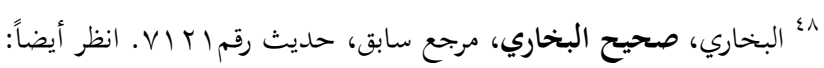

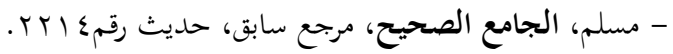

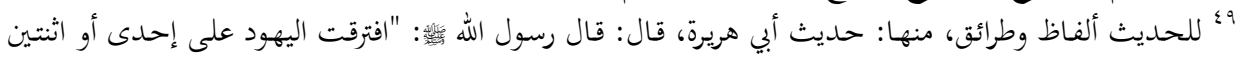

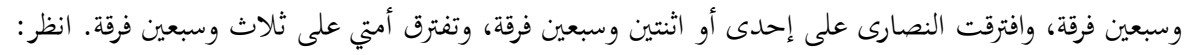

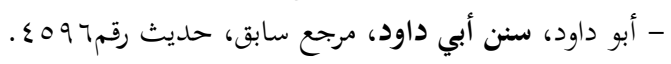

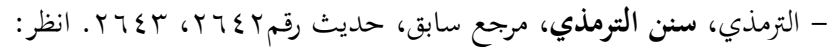

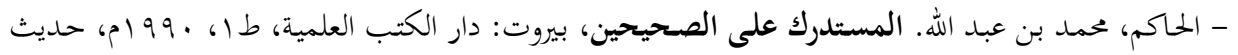

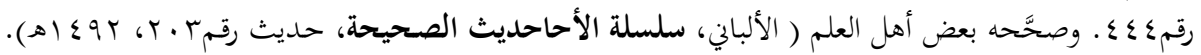

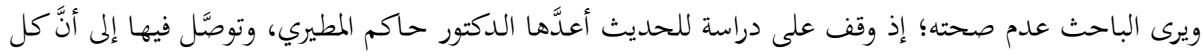

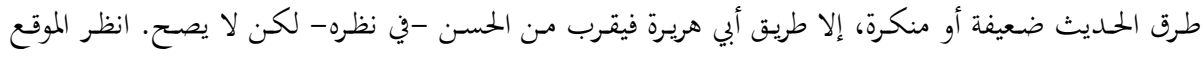

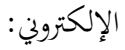
- نبراس الحق، حديث: الافتراق بين القبول والرد: - http://www.dr-hakem.com/portals/Content/?info=TmpJMEpsTjFZbEJoWjJVbU।R $\mathrm{PT} \cdot \mathrm{rdQ}==. \mathrm{jsp}$ 


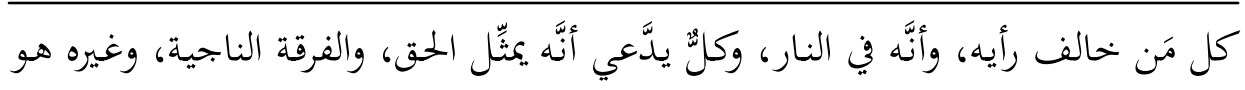

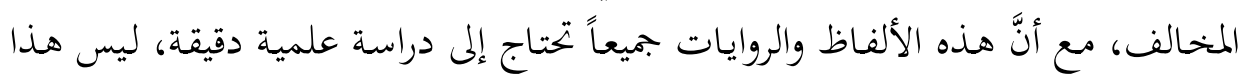
ميداغا.

ومن الأخطاء التي تشيع في هذا السياق تفسير الطائفة المنصورة ‘ْ بأَنَّا هي الفرقة

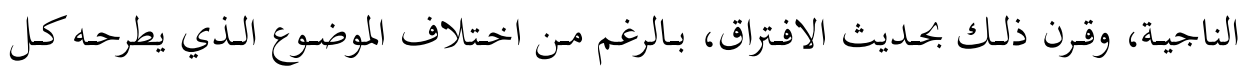

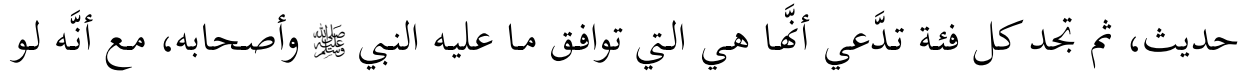

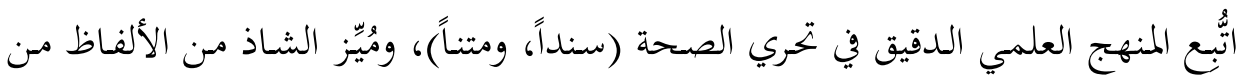
سواها، وجِمعت النصوص كلها لحسُن الفهم؛ سيخرج الجميع بنتائج مختلفة.

\section{Y I ا ـ النظرة السلبية إلى الفتن:}

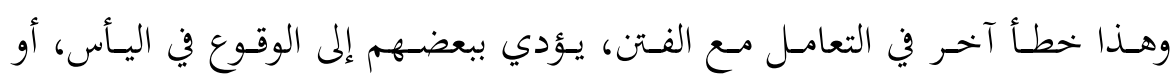

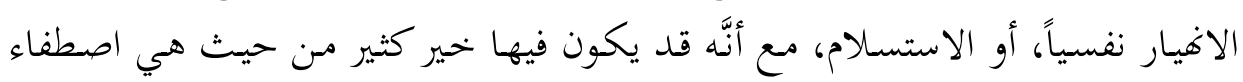

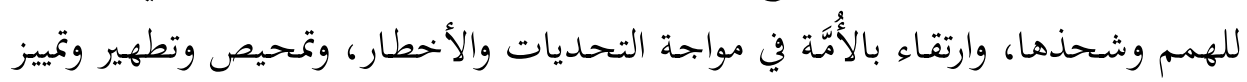

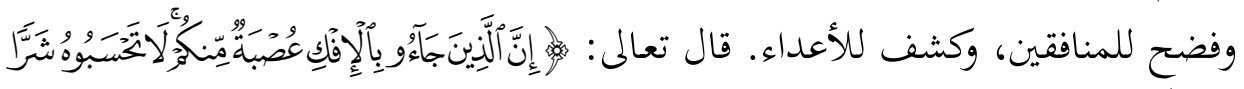

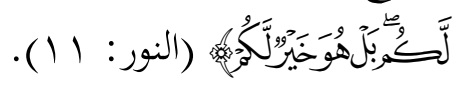

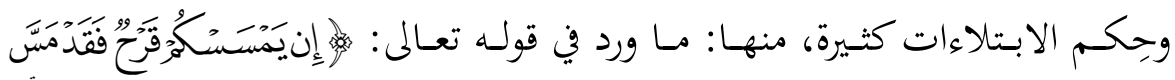

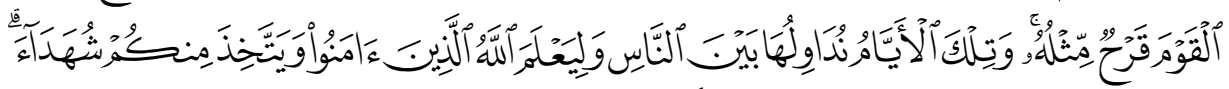

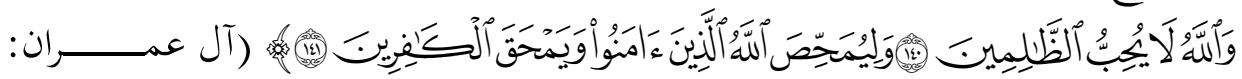

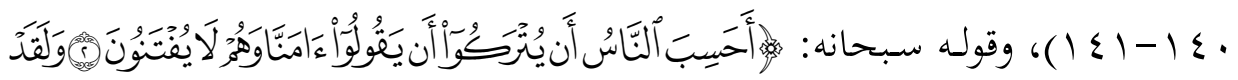

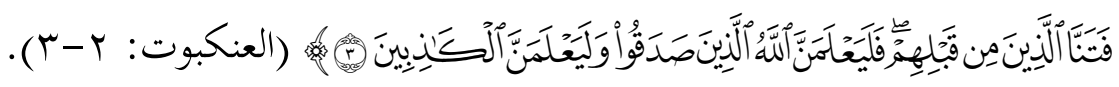

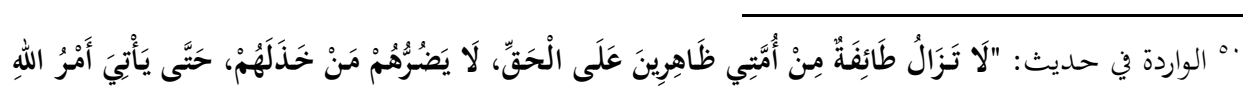

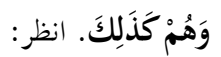

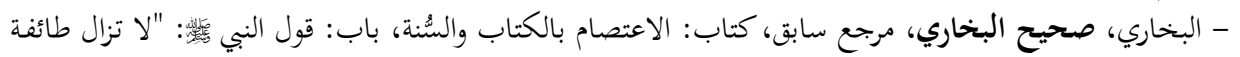

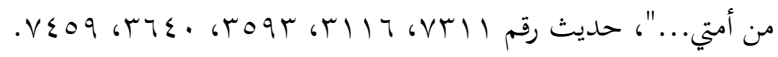

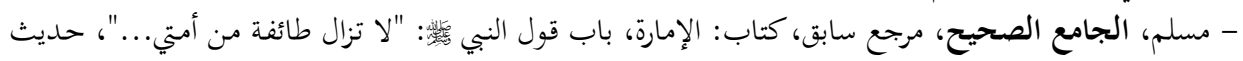

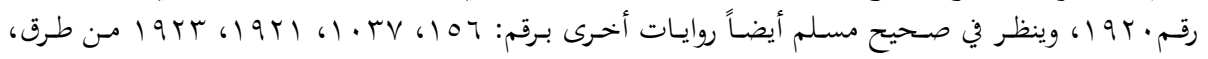




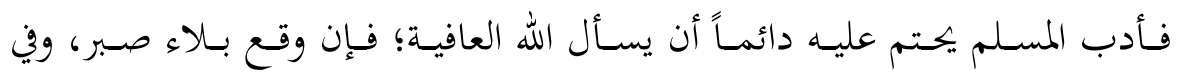

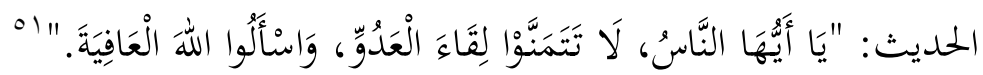

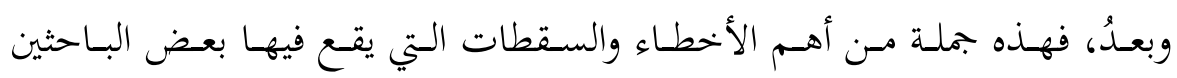

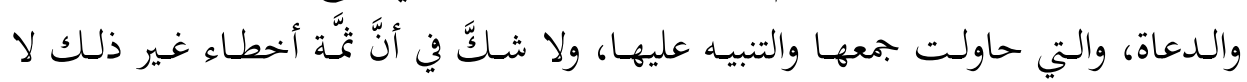
يتسع المقام لذكرها في هذا الموضع.

ثالثاً: قواعد وضوابط في منهجية التعامل مع أحاديث الفتن والمستقبل بعد أن استعرضنا أهم أخطاء بعض الباحثين والدعاة في تعاملهم مع أحاديث الفتن والمستقبل، فإنَّا نورد بعض الضوابط والقواعد التي يتعيَّن على الجميع اتباعها:

\section{1 ـ التحقّق من صحة الحديث؛؛ سنداً ومتناً:}

لئن كان ردُّ الحمديث الضعيف أمراً واضحاً، فإنَّ مما يلاحظ هنا أنَّ بعض الباحثين

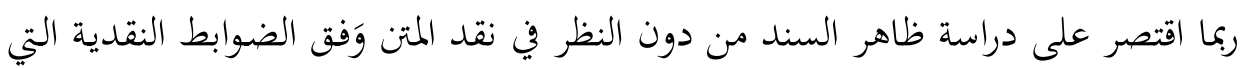

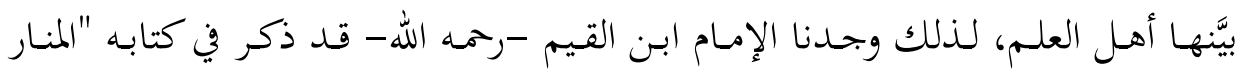

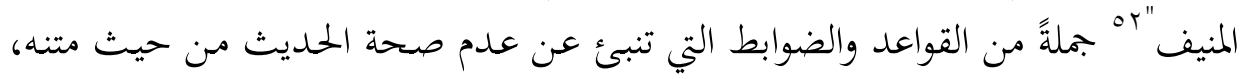

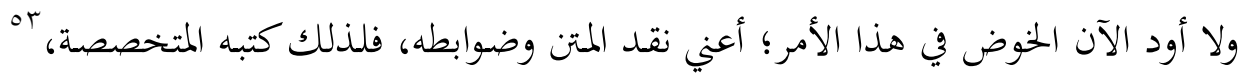

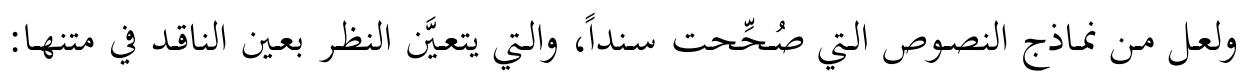

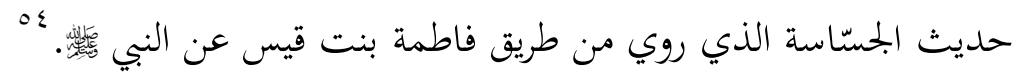

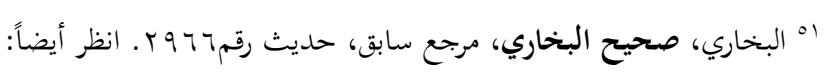

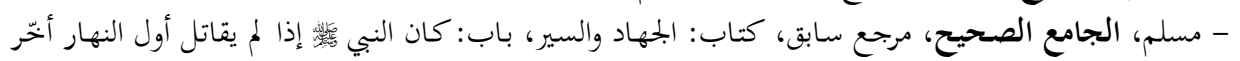

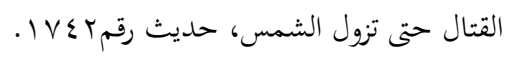

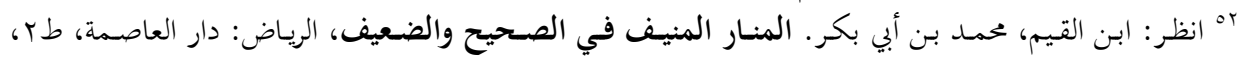

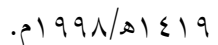

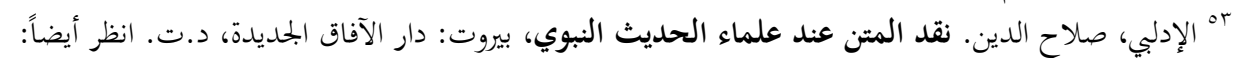

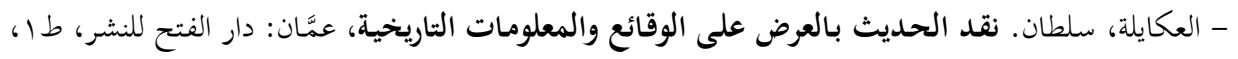

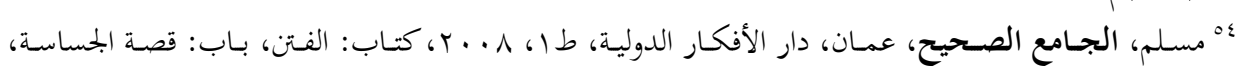




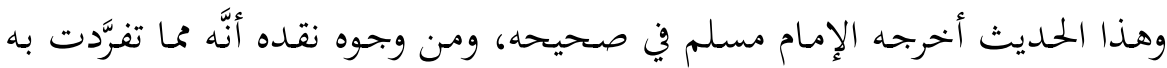

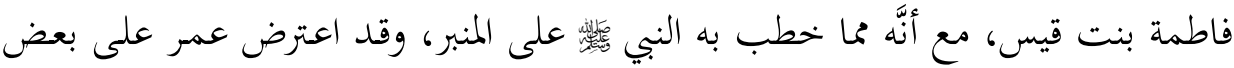

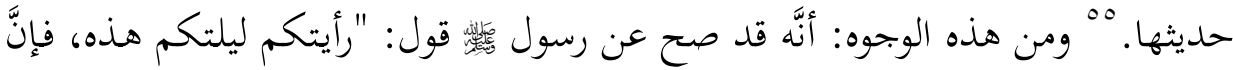

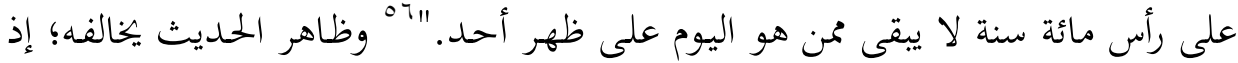

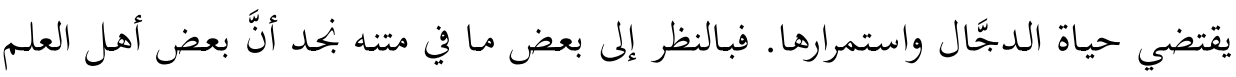

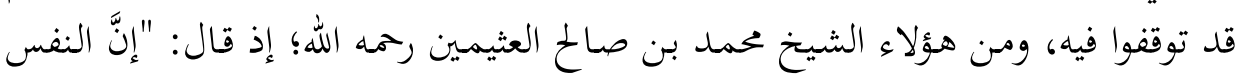

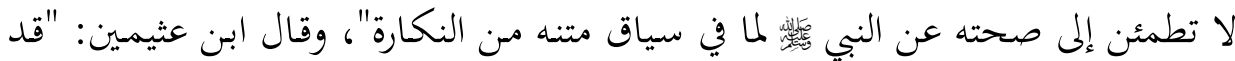

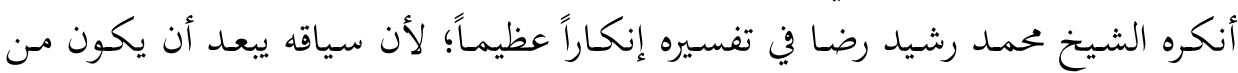

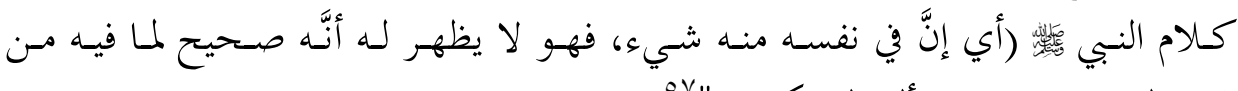
الاضطراب، وفي بعض ألفاظه نكارة).

قلت: قال رشيد رضا: "وبملة القول فيه أنَّ ما فيه من العلل والاختلاف والإشكال

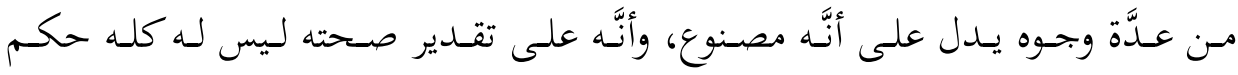

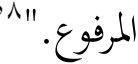

ولا بدَّ مـن الإشـارة هنا إلى الحـذر مـ دعوى العمل بالحمديث الضعيف؛ لأنَّ قضايا

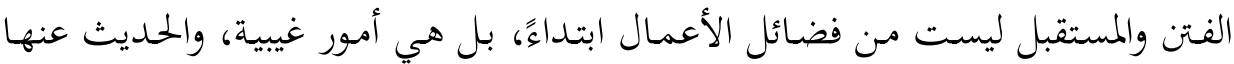

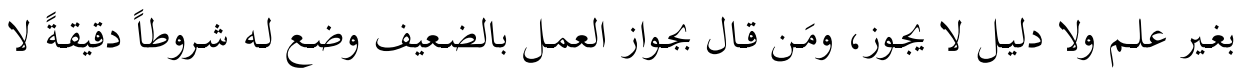
تنوافر هنا.

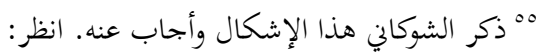

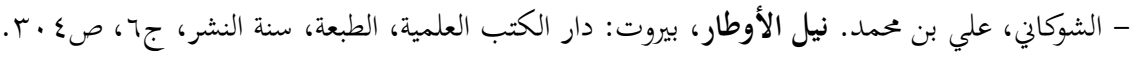

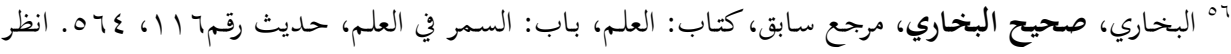

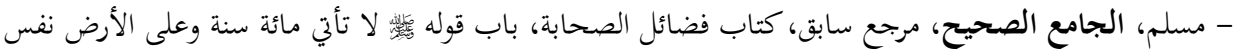

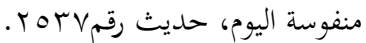

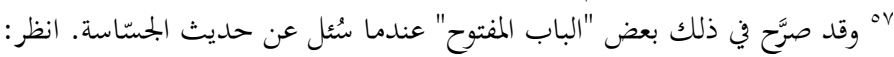

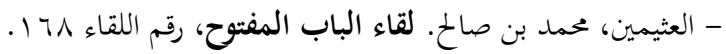

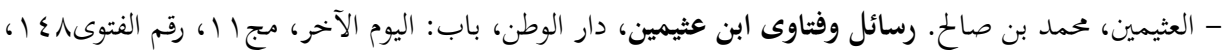
$.199 \varepsilon$

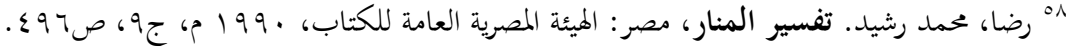

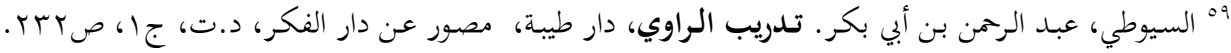




\section{r. - التحري في ألفاظ الحديث الصحيح نفسه:}

قـد يكون في بعض ألفـاظ الحسديث الصحيح ألفـاظ شـاذة، أو زيـادات لم يقبلها

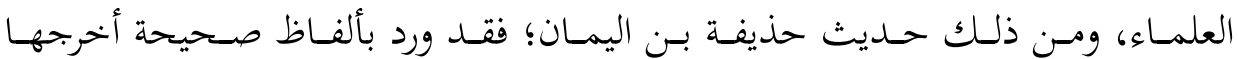

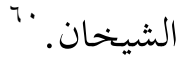

وقد أخرجه مسلم من طريق فيه زيادة بلفظ: "قال: تسمع وتطيع للأمير وإن ضرب

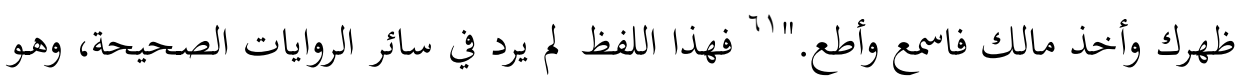

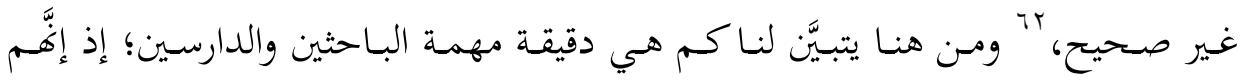

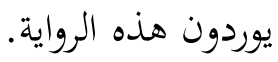

وبعضهم يورد حديث الطائفة المنصورة، بّثم يورد زيادة لا تصح، هي: "أنتم شرقي

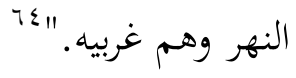

- القاسي، جمال الدين بن حممد سعيد. قواعد التحديث من فنون مصطلح الحديث، بيروت: دار إحياء الكتب

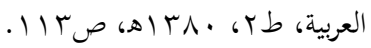

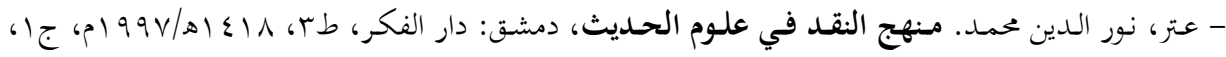

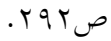
" البخاري، صحيح البخاري، مرجع سابق، كتاب: المناقب، باب: علامات النبوة في الإسلام، حديث رقم ؟ ب؟r.

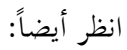
- مسلم، الجامع الصحيح، مرجع سابق، كتاب الإمارة، باب وجوب ملازمة جماعة المسلمين عند ظهور الفتن،

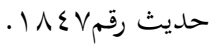
" مسلم، الجامع الصحيح، مرجع سابق، كتاب الإمارة، باب وجوب ملازمة جماعة المسلمين عند ظهور الفتن،

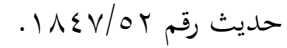

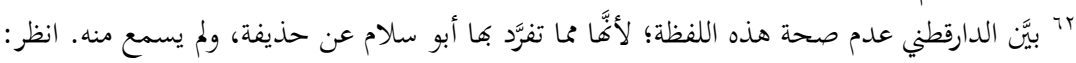

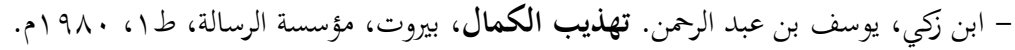
(t)

ك" أخرجها ابن أبي عاصم، في:

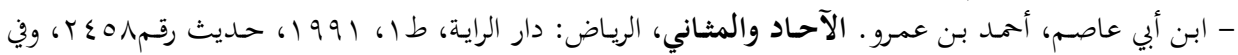

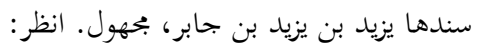

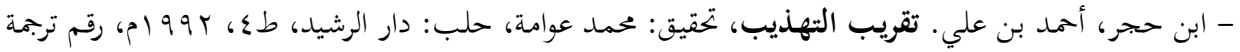

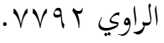

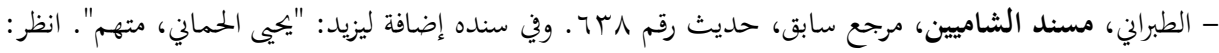

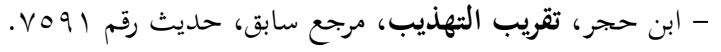




\section{ب. التحري في الفهم الدقيق للنصوص القائم على جمع الألفاظ وضبطها:}

يُشترط في هذا الفهم أن يكون قائماً على فهم الراسخين في العلم، ومنضبطاً بقواعد

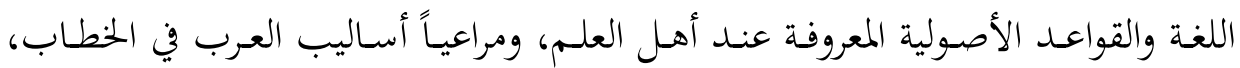
ومعرفة مدلولات الألفاظ، وملاحظة النظرة الشمولية إلى النصوص بعيداً عن التأويل من ونمريه

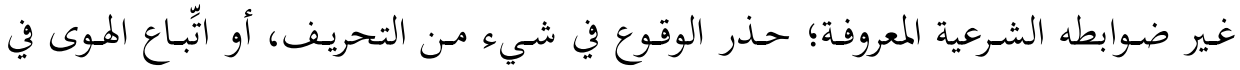

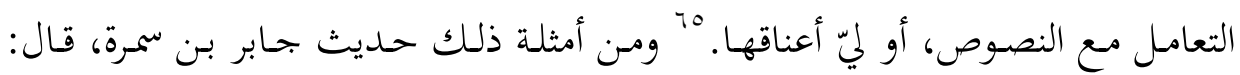

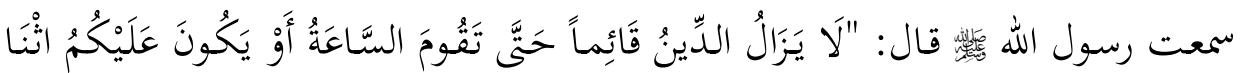

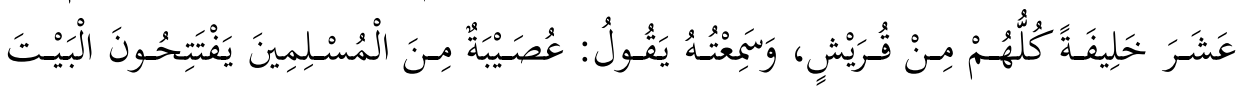

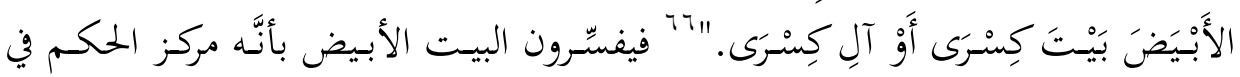
أمريكا.

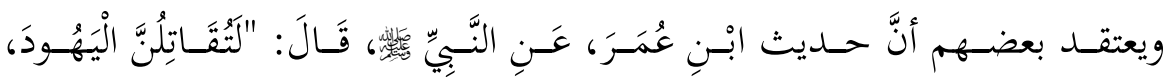

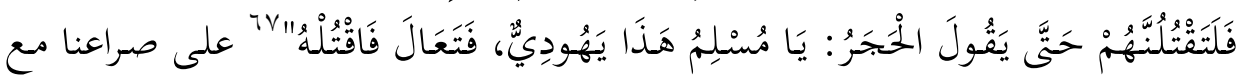

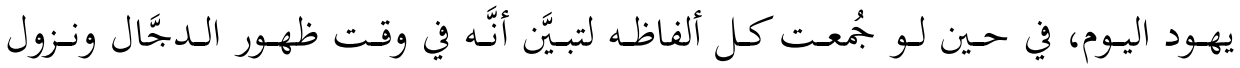

\section{ع. البُعْد عن التنزيل الخطأ أو المتسرع على الواقع:}

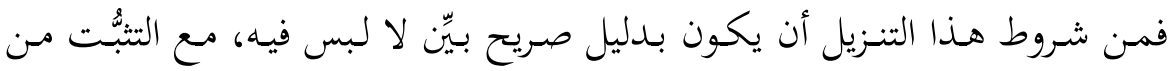

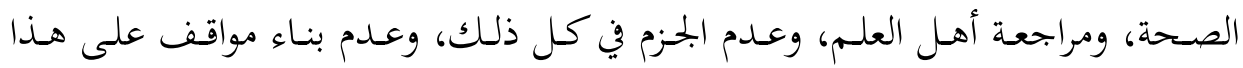

وقد انقلبت عند الطبراني، فجعل المسلمين غربي النهر، ثم فيه: "ذكر الدجال أو المشركين وليس اليهود".

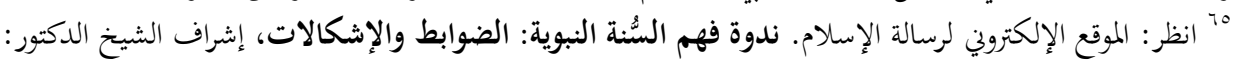

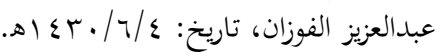

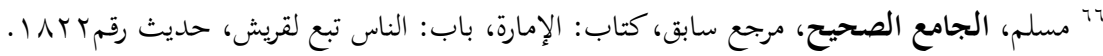

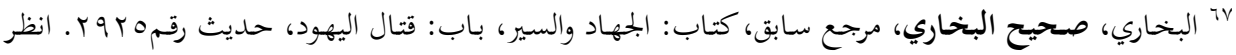
- مسلم، الجامع الصحيح، مرجع سابق، كتاب: الفنن، باب: لا تقوم الساعة حتى يمر الرجل بقبر الرجل، حديث 


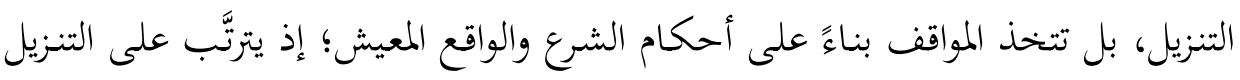

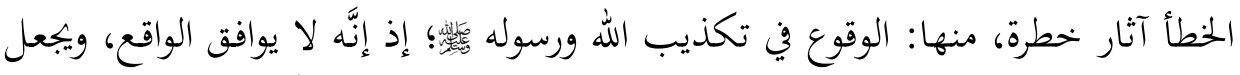

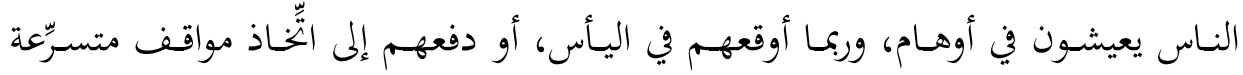

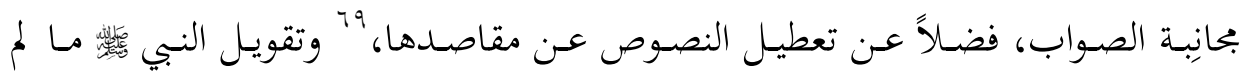

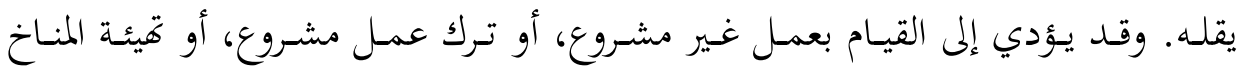

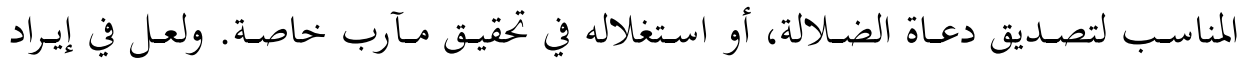
بعض الأمثلة على التنزيل الخطأ ما يوضِّح الأمر:

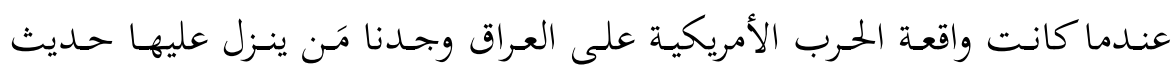

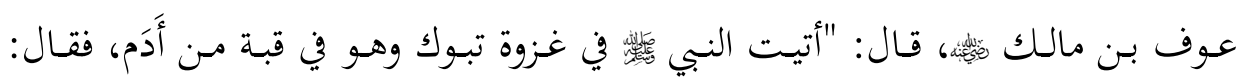

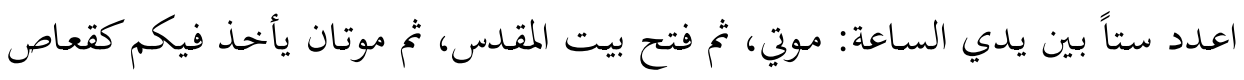

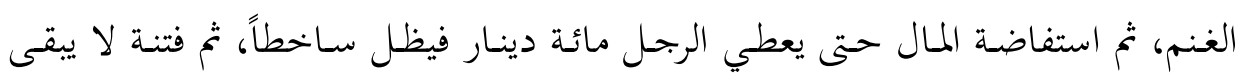

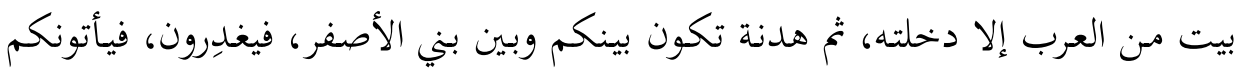

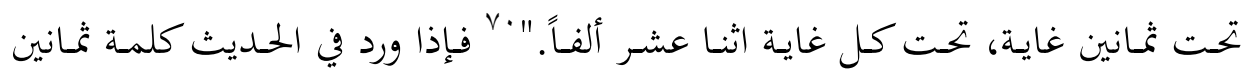

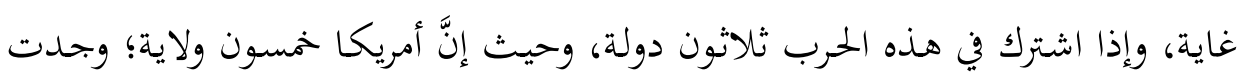

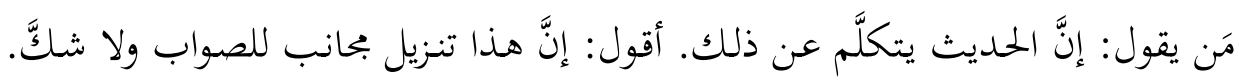

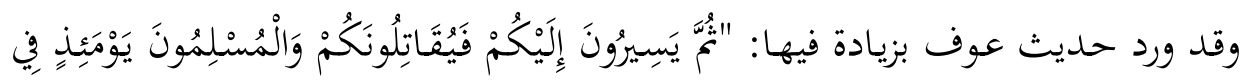

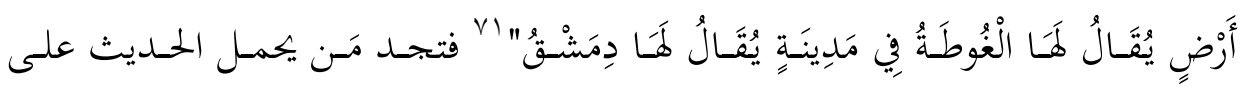
أحداث سوريا اليوم. 99 "9 العجيري، عبد الله بن صالح. معالم ومنارات في تنزيل أحاديث الفتن والملاحم وأشراط الساعة على الوقائع

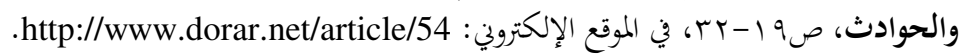
وانظر سرد بعض الكتب التي ينبغي الحذر منها مما ينزل النصوص تنزيلاً غير صحيح، أو يعتمد ما لا يصح، في

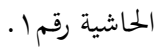

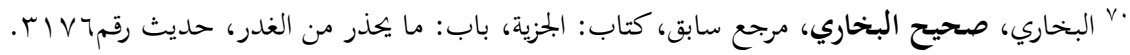

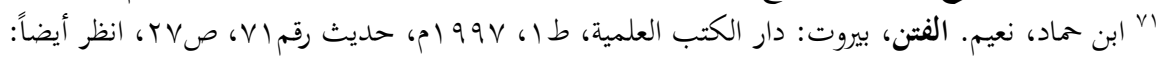

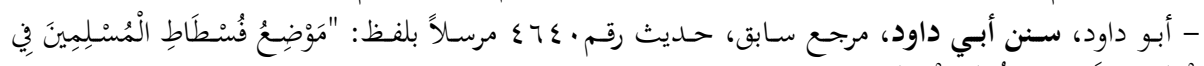

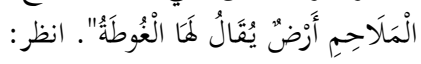

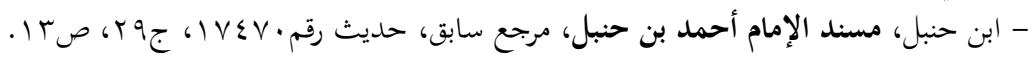




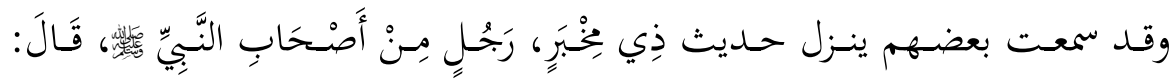

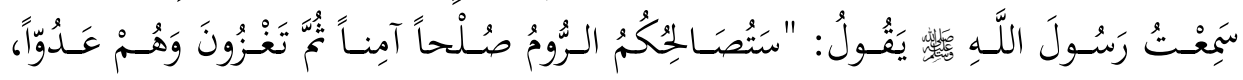

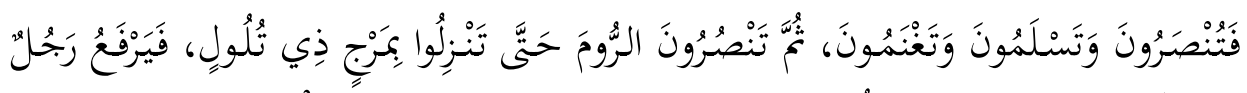

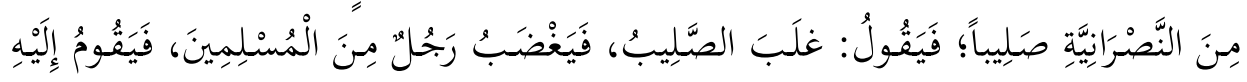

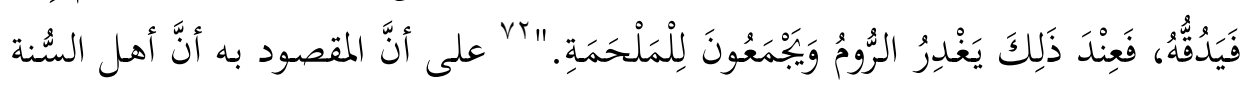

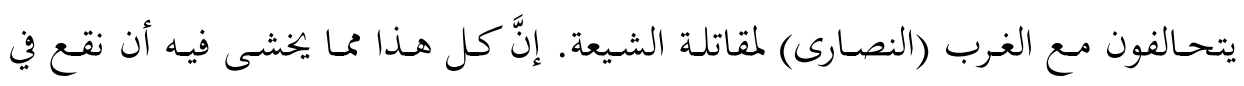

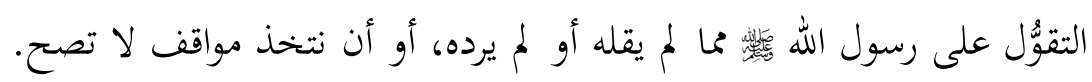
ومن الأمثلة في هذا الصدد الحصار الذي تعرَّض له العراق؛ فقد أخذذ بعضهم يردِّدُ

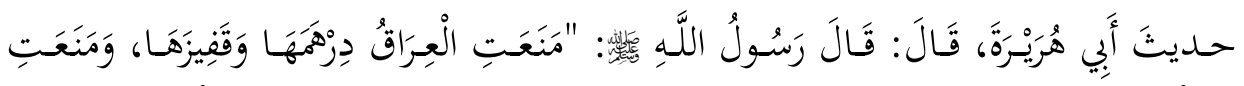

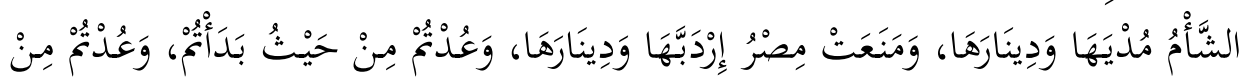

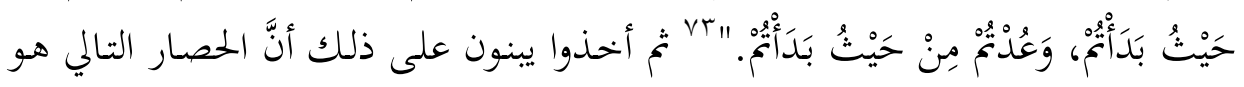

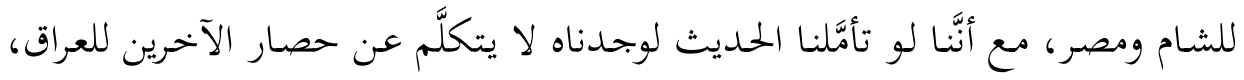

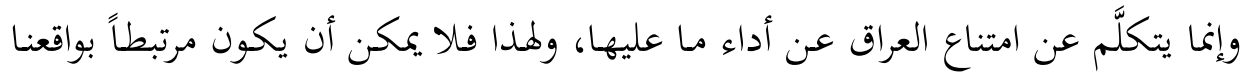

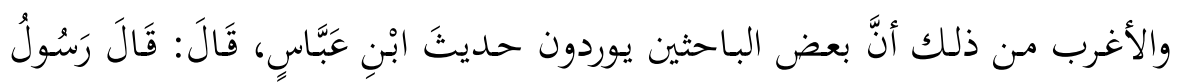

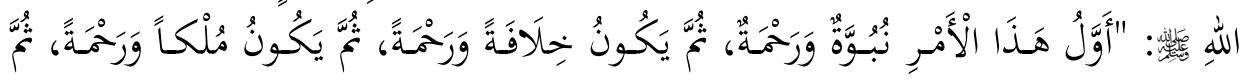

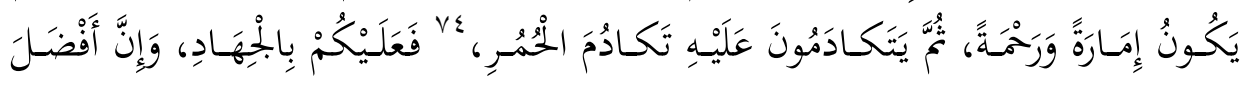

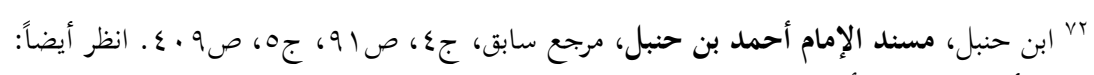

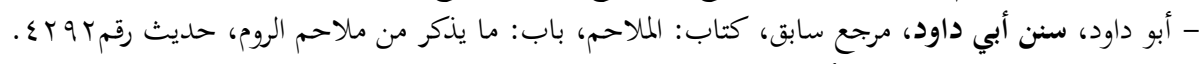

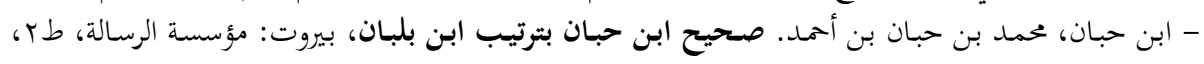

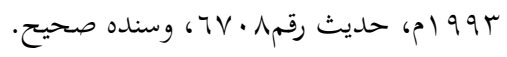

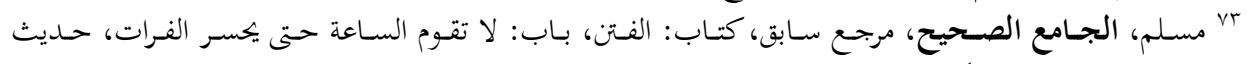

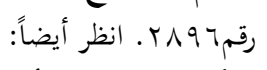

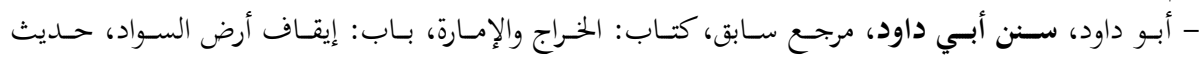
رقمهr.r.

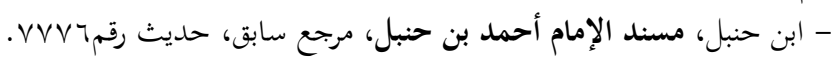

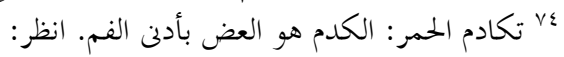

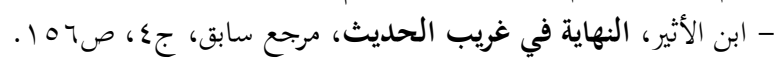




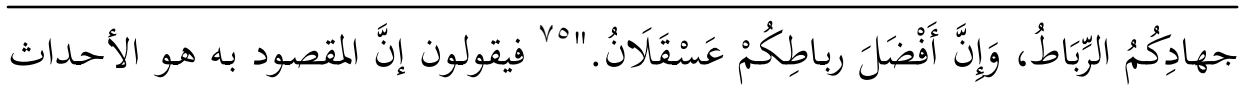

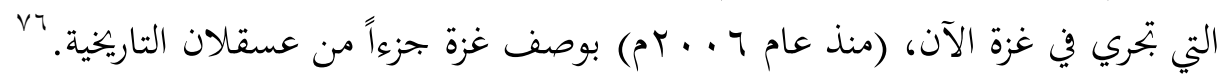
ومسن النماذج الخطيرة في سوء التنزيل والفهمه، مع أفَّا لا تصح، مـا رواه أبو نعيم،

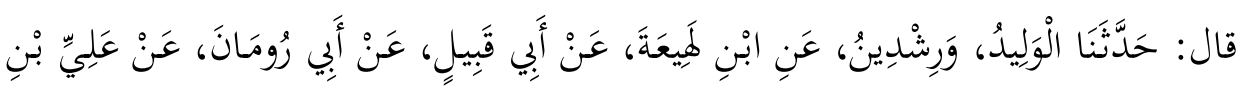

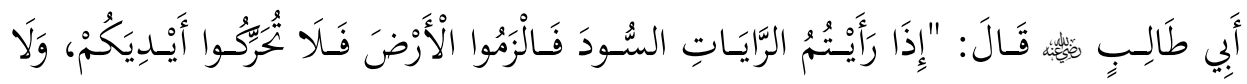

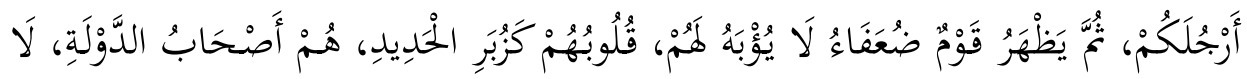

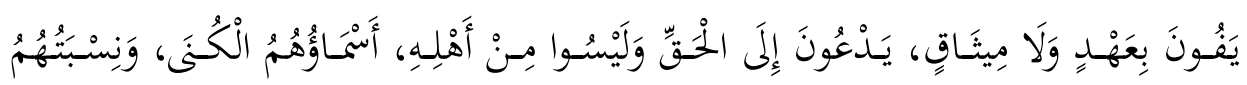

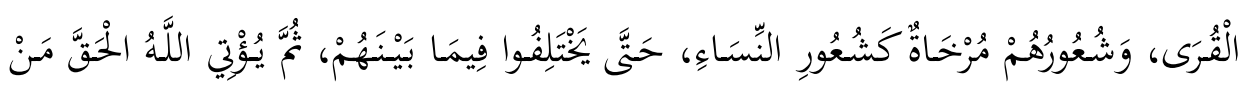

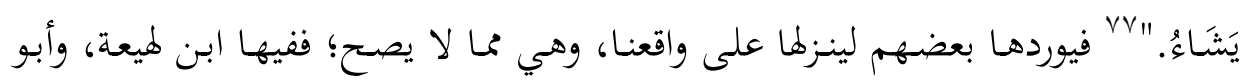

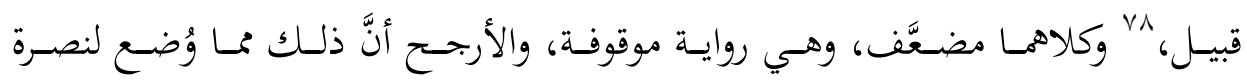
العباسيين، بدليل الرواية الآتية، وإن كانت لا تصح أيضاً:

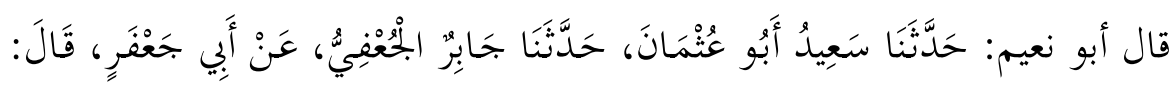

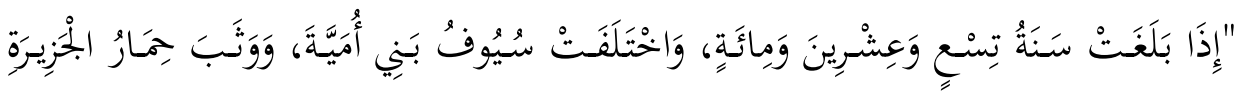

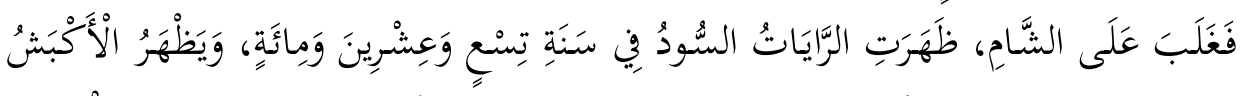

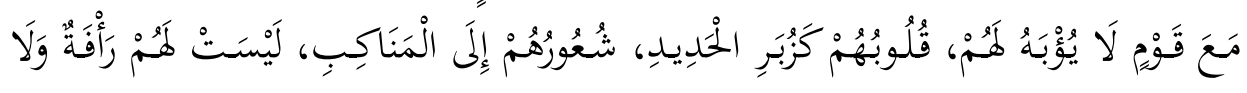

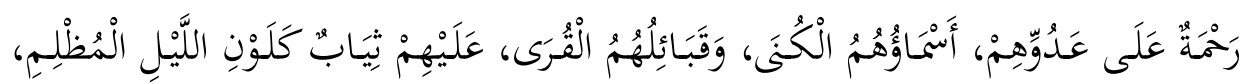

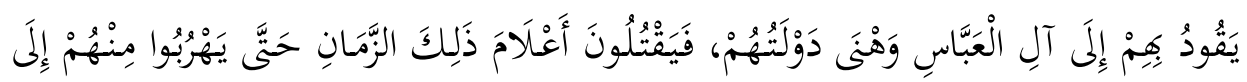

- الرازي، زين الدين أبو عبد الله محمد بن أبي بكر. مختار الصحاح، بيروت: المكتبة العصرية- الدار النموذجية،

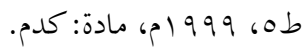

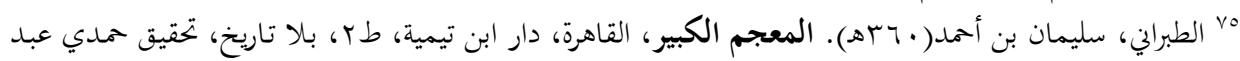

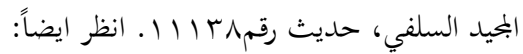

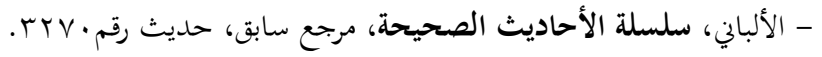

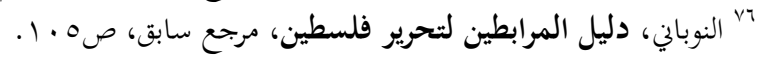

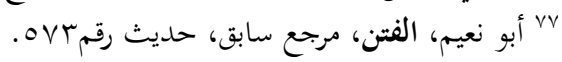

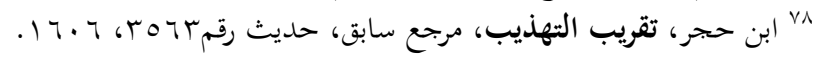




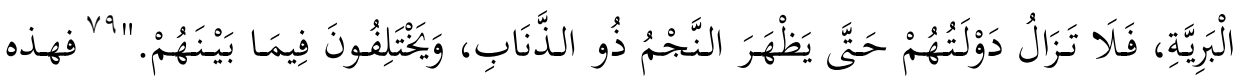
الرواية لا تصح؛ إذ إنَّ فيها الجعفي، وهو متهم، لُ وهي معضلة.

هـ سـياق أحاديسـ الفـتن والمسـتقبل في إطـار مـن إدراك كامـل لمقاصــهـا

وحكمها:

ويشمل ذلك عرض الأحاديث بما يكقِّق هذه المقاصد والمِكِم، مثل الإشارة إلى أََّّا من أعـلام النبوة، ومن وجوه معجزات النبي إن صحَّت وثبتتت، وسياقها يعزِّز الإيمان في القلب، ويجعل منها تنبيهاً للأُمَّة أو تحذيراً لها أن تقع في أسباب هذه الفتن، وإن وقعت؛ فلكي تسعى الأمـة إلى العـلاج وَفـق الهـدي النبـوي، وأن تسـاق هـذه الأحاديـث لتحريـر المسـلم مـن الخـور والضعف والمزيمـة النفسية، ولبـث الأمل في النفوس؛ اء إذ إنَّ كثيراً مـن

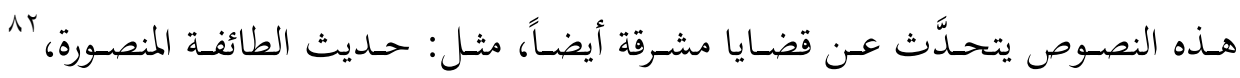

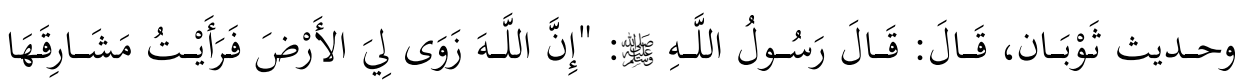

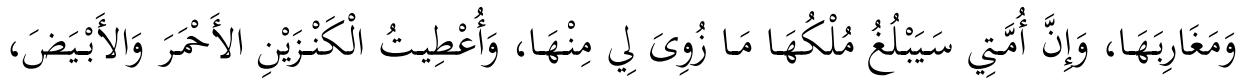

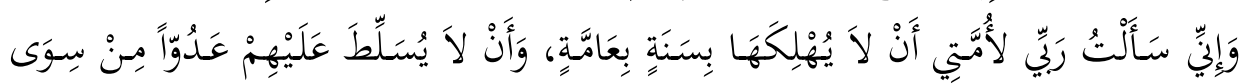

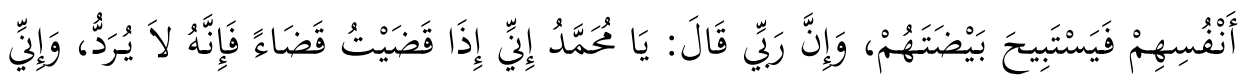

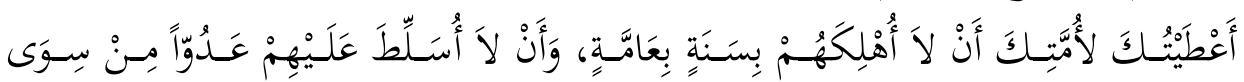

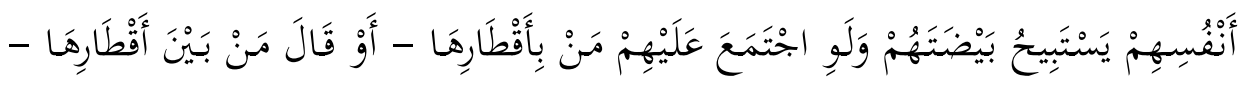

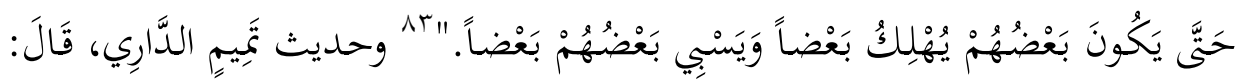
سَمِعْتِ رَسُولَ اللَّهِ Va

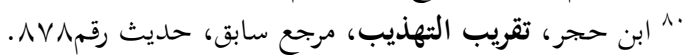

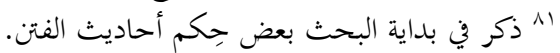
مr

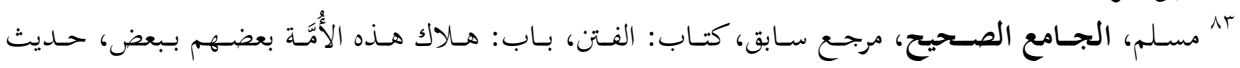

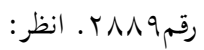




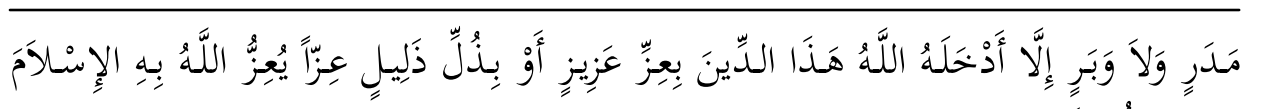

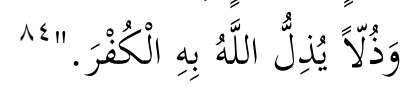

وأن تساق هذه النصوص ليستضاء بها في فهم الواقع المعيش، مع دقة المعالجة، كما أشرنا من قبل، في التحذير من التنزيل الخطأ.

\section{7. النظرة الشاملة، وعدم النظرة الجزئية إلى النصوص:}

يغلب على بعض الدارسين والباحثين التعامل مع النصوص بحزَّأةً من غير أن تكون

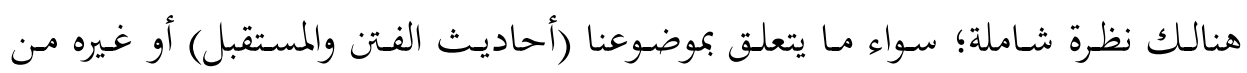

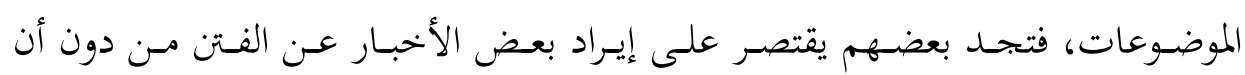

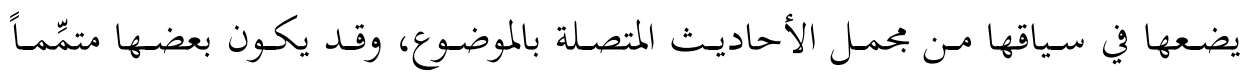

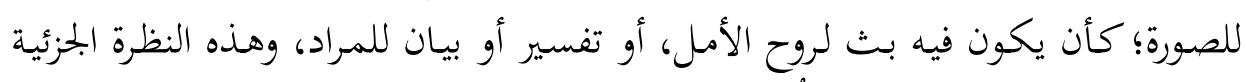

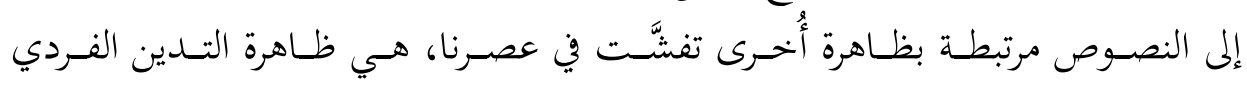

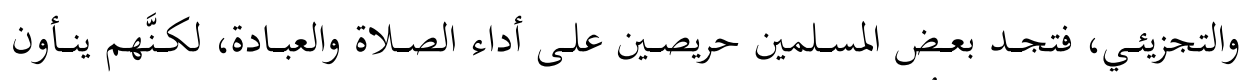

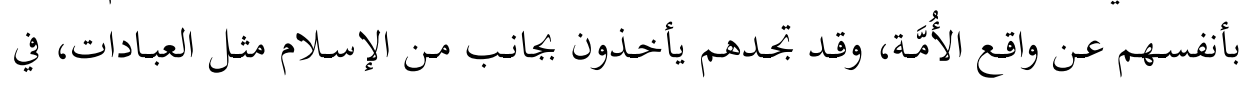

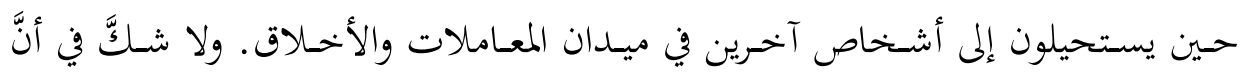

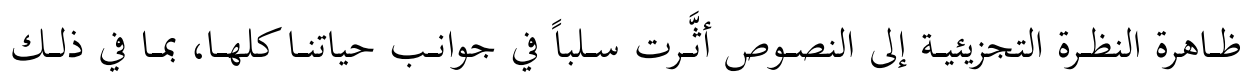

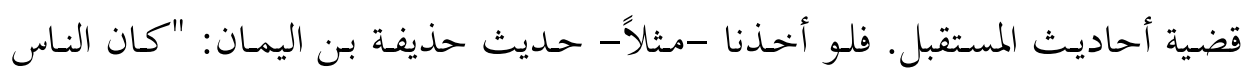

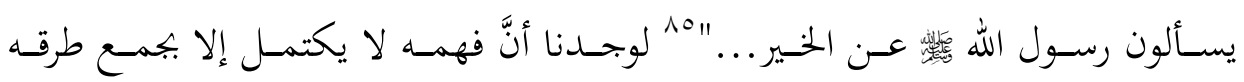

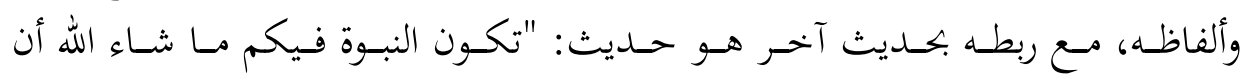

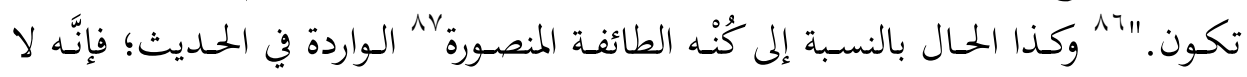
يمكن تحديدها إلا بجمع ألفاظ الحديث كلها.

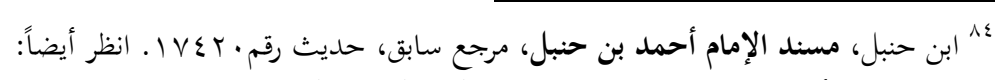

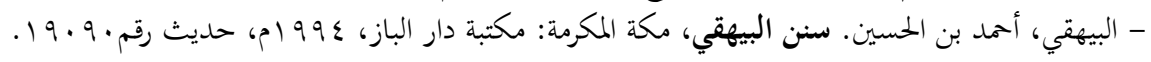

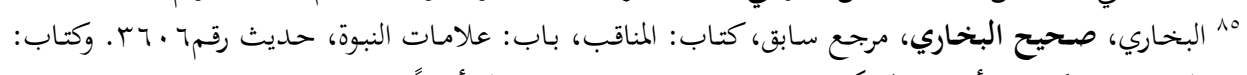

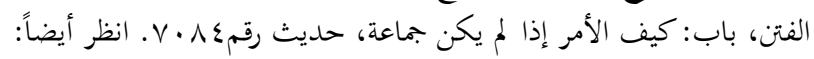

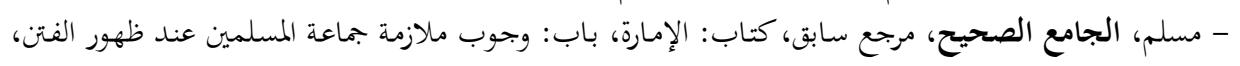

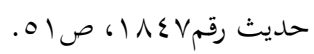

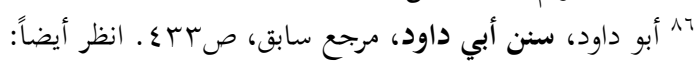


V. الاقتصار على نصوص القرآن والسُّنة، والبُعْد عن المصادر الأُخرى:

فقـد لاحظنـا أنَّ بعض الدارسـين والدعاة ربمـا يرجعون إلى كتـب غير موتَُّّة، مثل:

كتاب "الجفر "، وكتاب "شمس المعارف"، أو كتب جمعت الغتث والسمين، مثل كتاب: "عقد الدرر في أخبار المهدي المنتظر" للسلمي، وكتاب "الفتن والملاحم" لنعيم بن حماد المروزي، حتى إنَّ بعضهم قد يلجأ إلى الروئ والمنامات، وكل ذلك من الأخطاء الخطيرة،

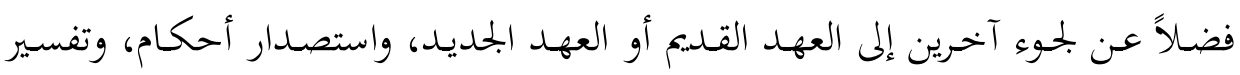

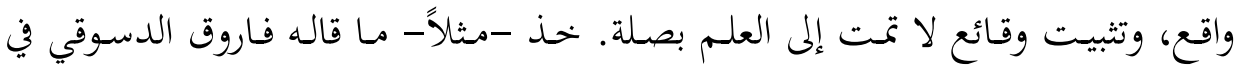

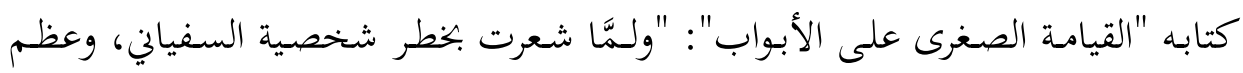

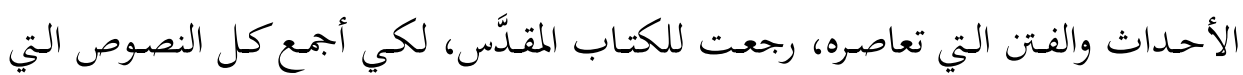

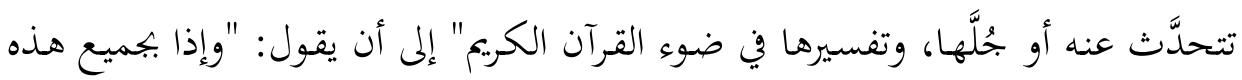

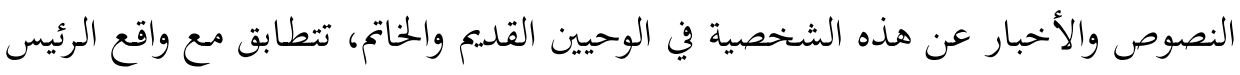

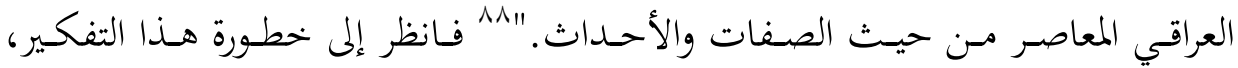
وخطورة هذه المنهجية، مع أنَّ شيئاً من ذلك لا لا يصح.

A. مراجعة العلماء المحققين قبل القطع بثبوت حديث، أو فهم ما، أو تنزيل

على واقع:

إذ يلزم التحري الشديد والتأني في ذلك؛ فقد بحد بعض الباحثين والأئمة يسارعون إلى تنزيلٍ لإثبـات قدرقم على الاكتشـاف والمعرفة، وعلى هـا المنهج في التحري جـرى

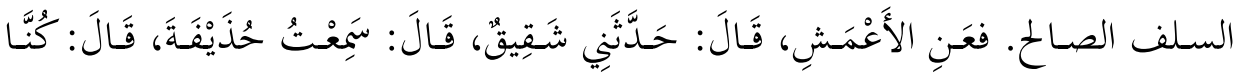

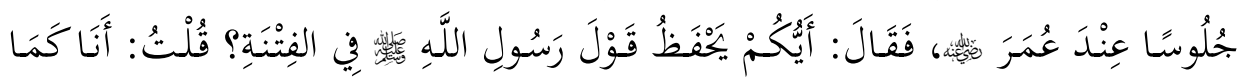

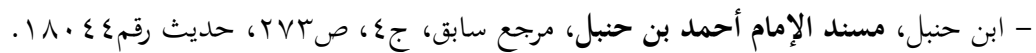

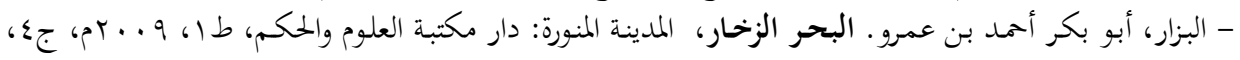

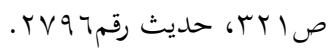

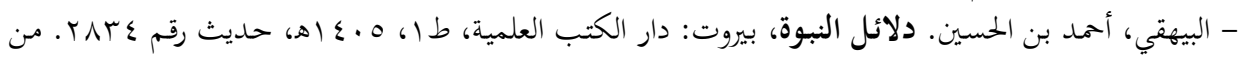

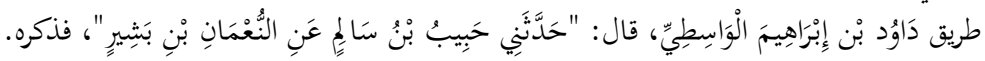
NV

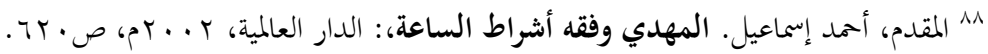




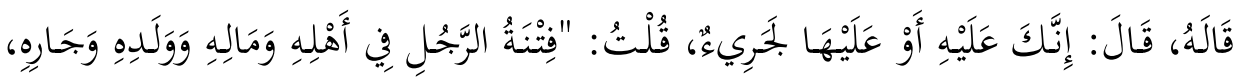

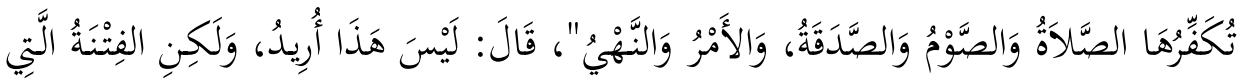

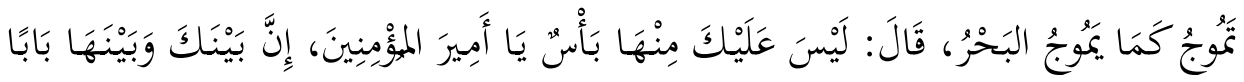

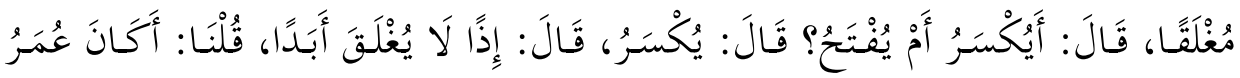

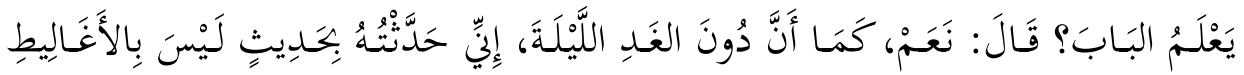

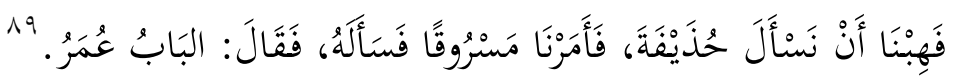
وفي حديث أبي نضرة، قال: كنَّا عند جابر بن عبد الله فقال: يوشك أهل العراق أن لا يجبى إليهم قفيز ولا درهم، قلنا: من أين ذاك؟ قال: من قبل العجم يمنعون ذاك، ثم

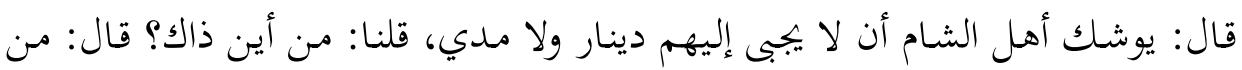

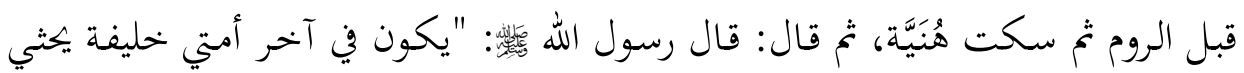

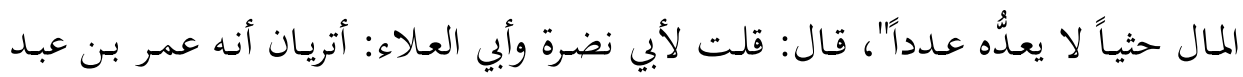

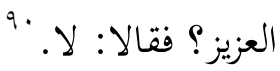

\section{9 ـ البُعْد عن المشكل من الروايـات إذا كان المتحدِّث ممن لا يستطيع إزالة

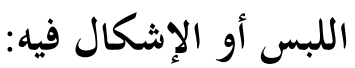
ولعل من أمثلة ذلك حديث ابن صياد، "و وفيه إشكالات كثيرة؛ به إذ يصوّر النبي

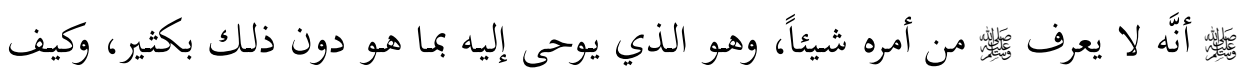
هُ البخاري، صحيح البخاري، مرجع سابق، كتاب: مواقيت الصلاة، باب: الصلاة كفارة، حديث رقمه ب. انظر

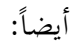

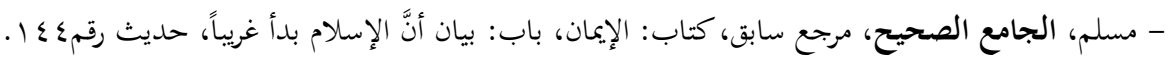

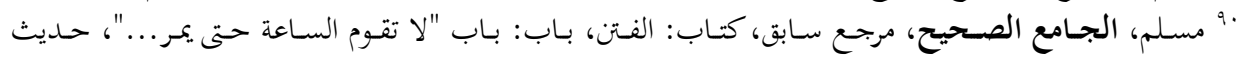

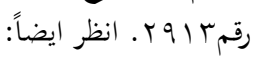

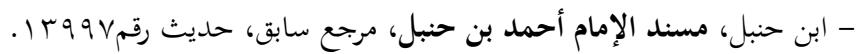

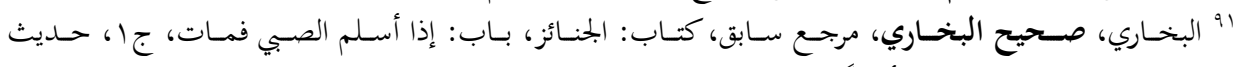

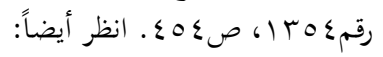

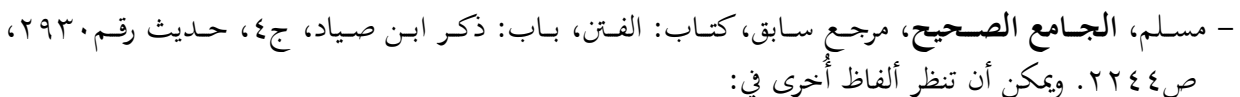




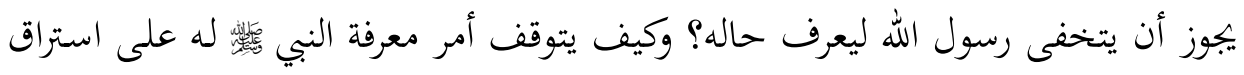

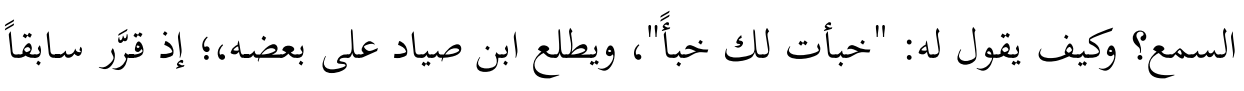

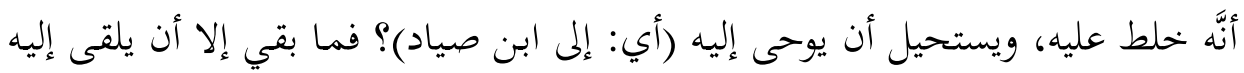

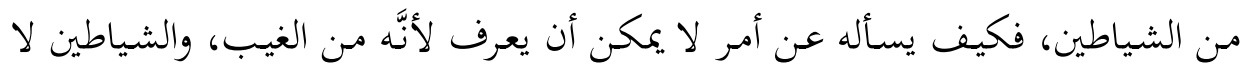

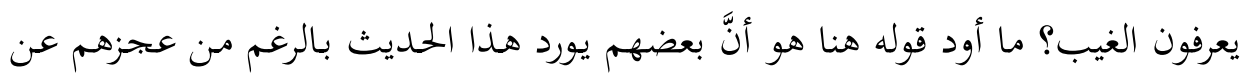
تنقية هذه الروايات، أو الإجابة عن إشكالاتحا.

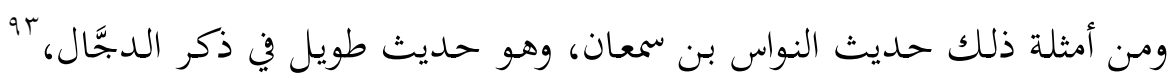

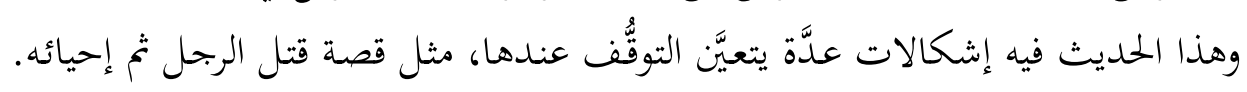

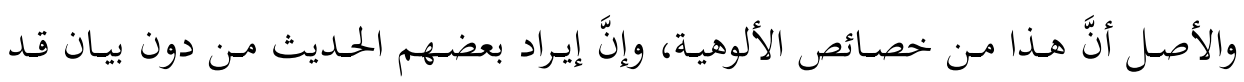

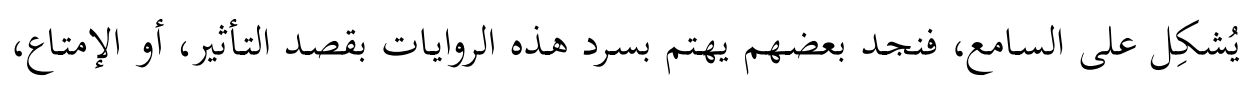
أو الإغراب من دون قدرة على البيان، أو النقد، وإزالة الإشكال.

\section{• 1 ـ البُعْد عن التكلُفف في فهم النصوص:}

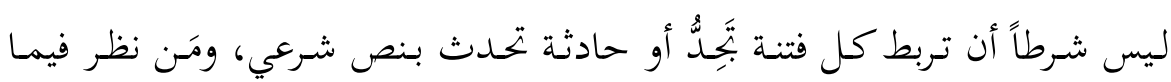

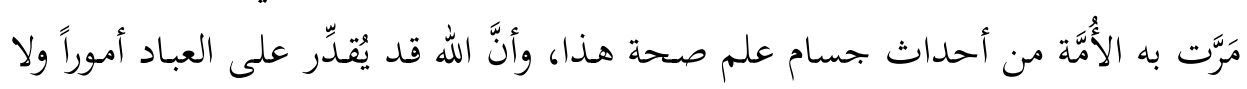

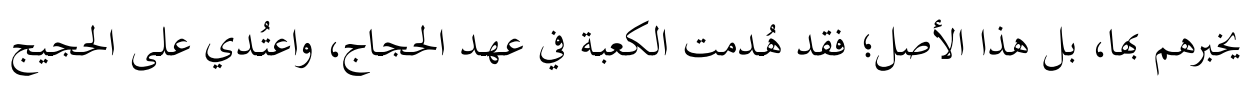

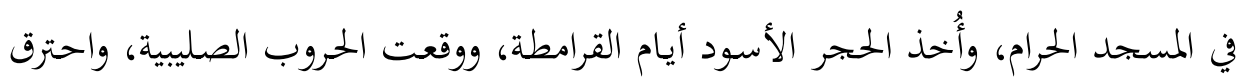

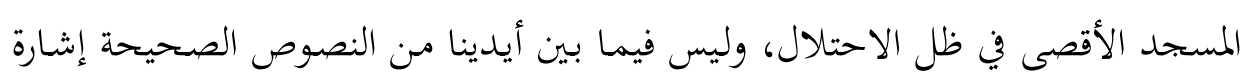

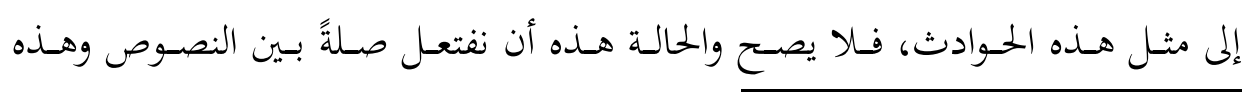

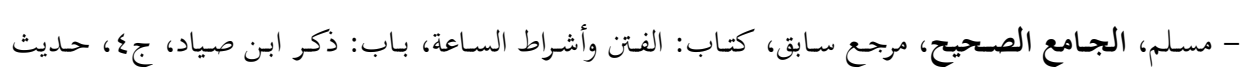

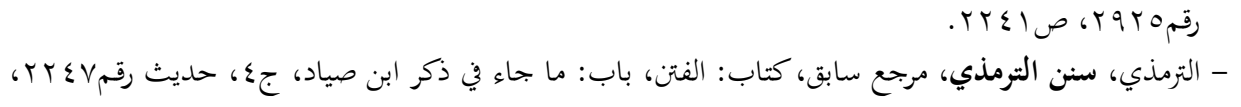
$.01 V 0$

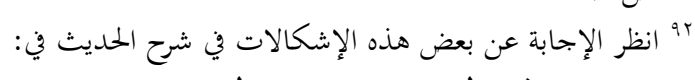

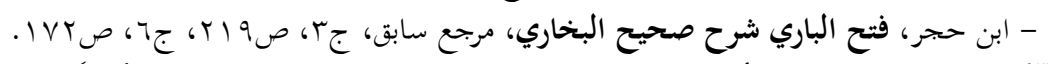

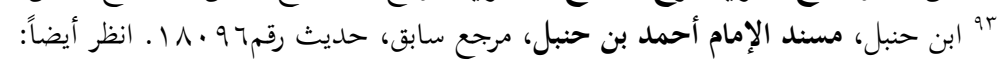

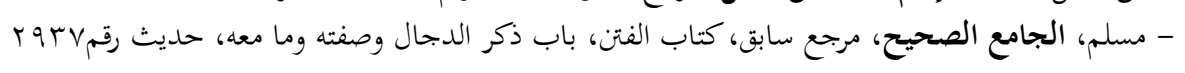




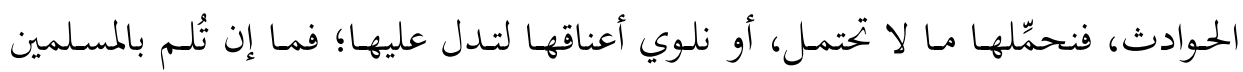

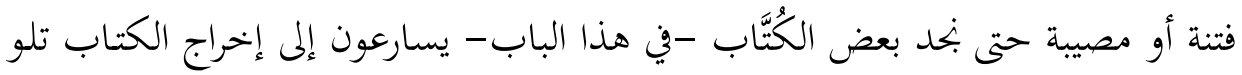

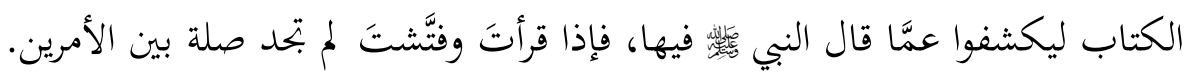

\section{1. عـدم تحديـد تواريخ وأوقات معينـة لوقوع الفتن والملاحم أو الأحسداث}

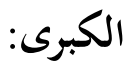

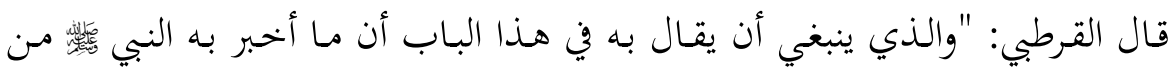

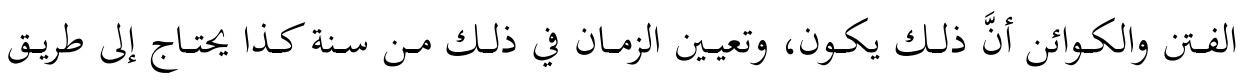

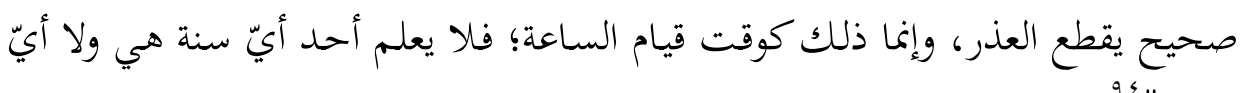
شهر." شع

ونظراً إلى وجود نصوص تتحدَّث في ظاهرها عن مقدار عمر الأَمَّة، مثل حديث ابْنِ

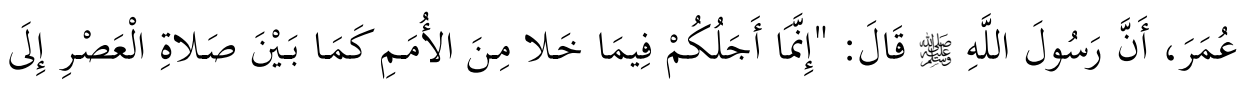

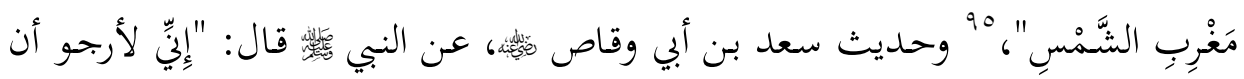

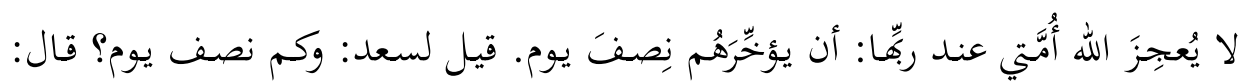

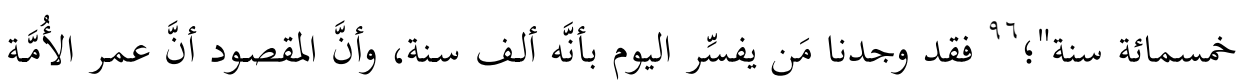

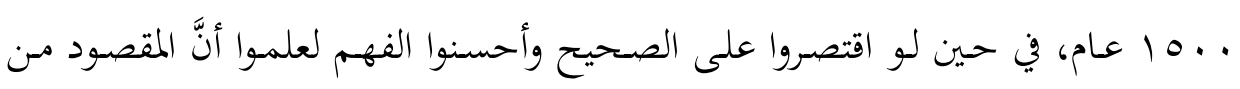

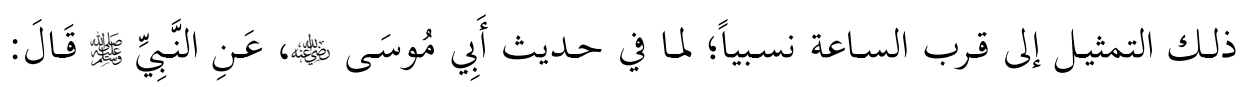

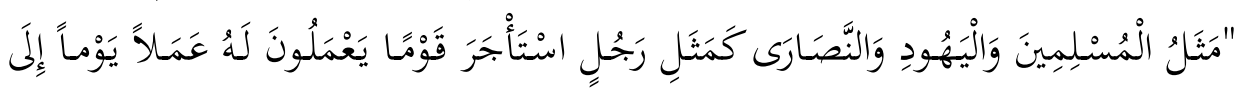

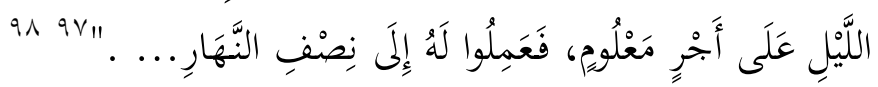

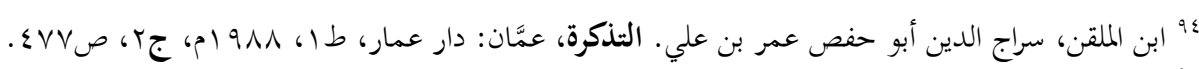

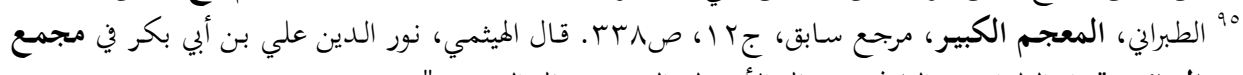

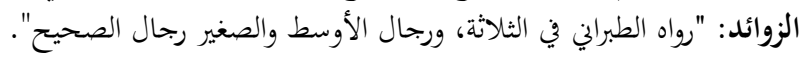

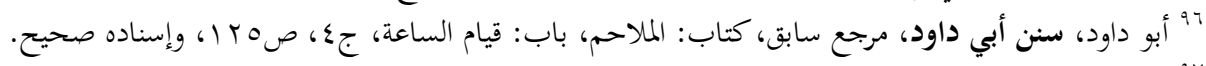

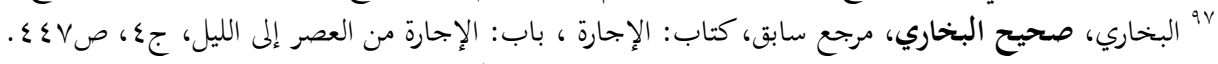

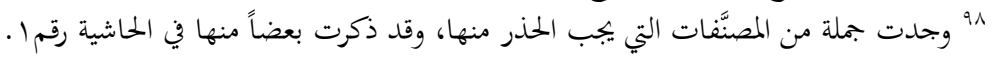




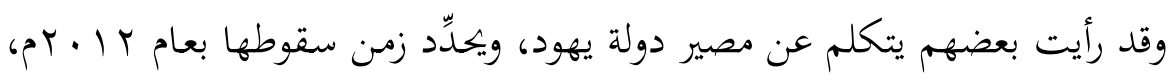

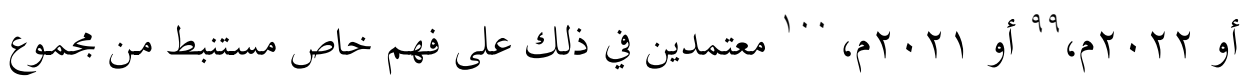

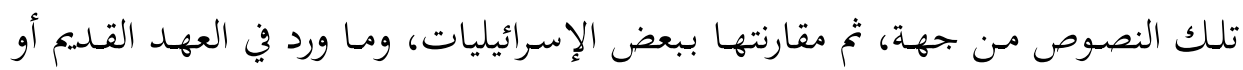

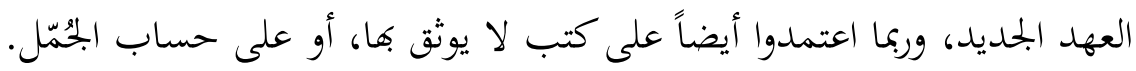
وربمـا جـزم بعضهـم فيمـا توصَّل إليه، وهـذا كله ممـا لا ينبغي؛ إذ إنَّ مـنهج القـرآن

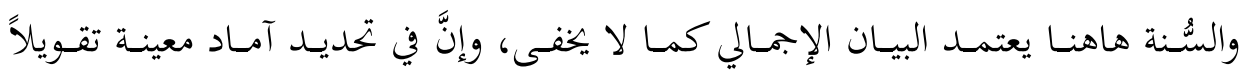

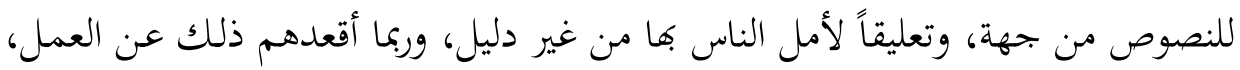

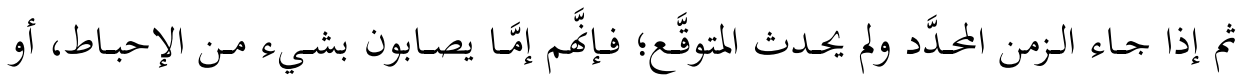

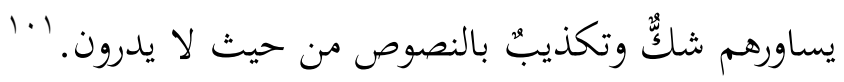

ومن هذا الباب ربمـا تعجَّل بعضهم في ترتيـب علامات السـاعة من غير جمع دقيق للنصوص.

\section{ץ ا ـ الإيجابية في التعامل مع النصوص، والبُعْد عن القدرية الاستسلامية في

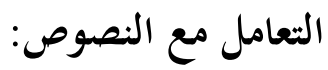

لا شلكَّ في أنَّا نؤمن بكل ما صح عن الله ورسوله من أخبار المستقبل، وأنَّا واقعة

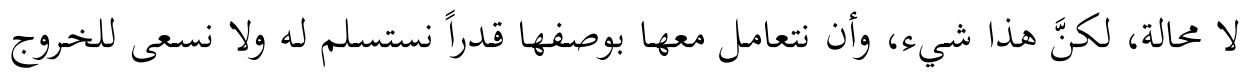

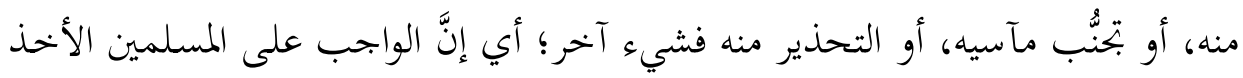

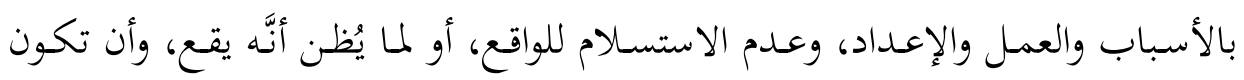

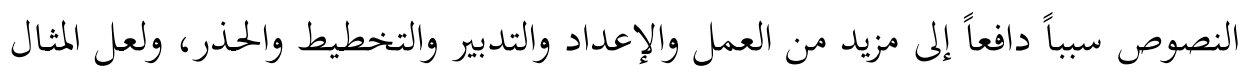

$$
\text { 999 الآتي يوضِّح هذا الأمر. }
$$

- http://www.alhawali.com/main/5898-2

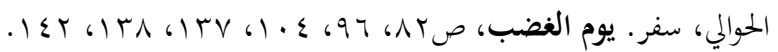
- http://www.islamnoon.com/Derasat/Books_PDF/zawal.pdf

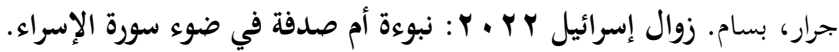

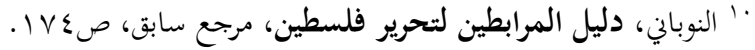

$$
\begin{aligned}
& \text { 1. }
\end{aligned}
$$




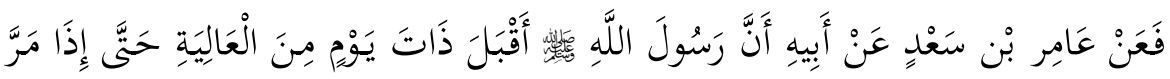

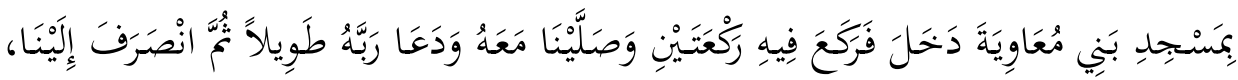

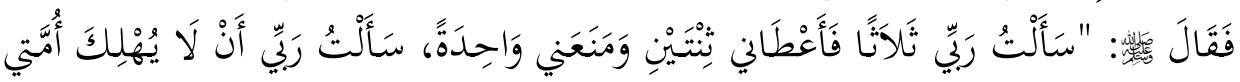

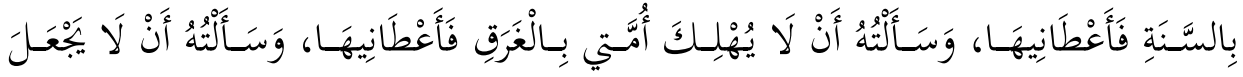

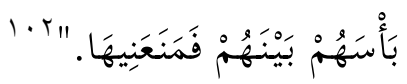

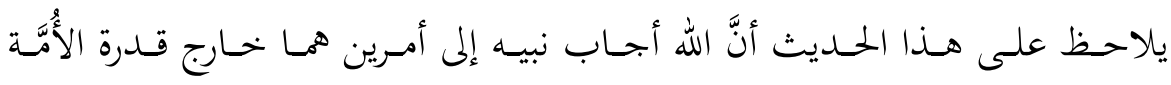

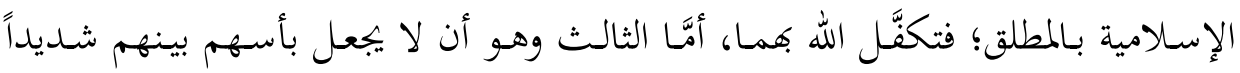

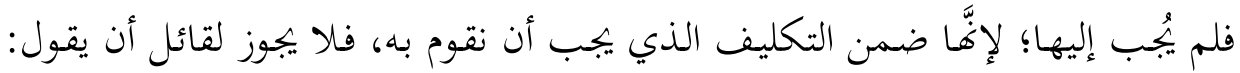

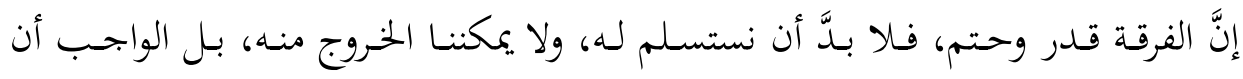

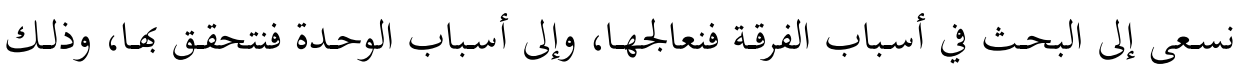

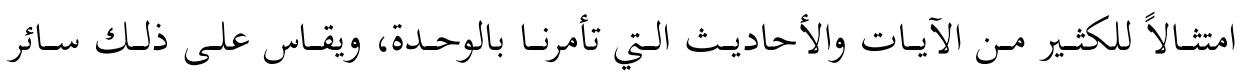

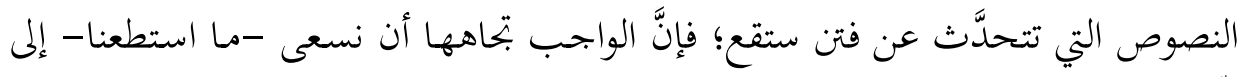

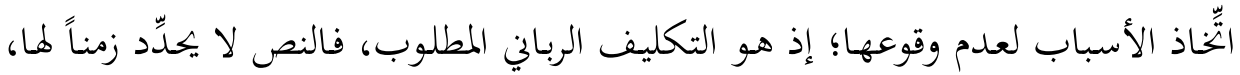

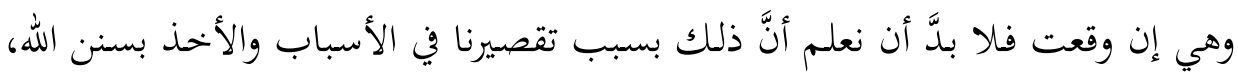

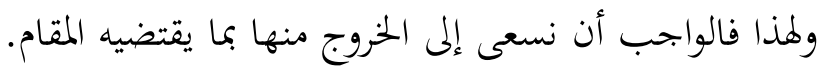

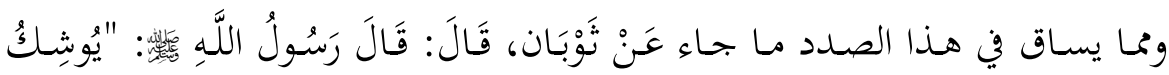

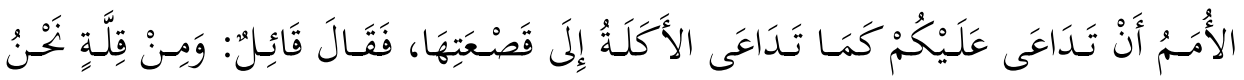

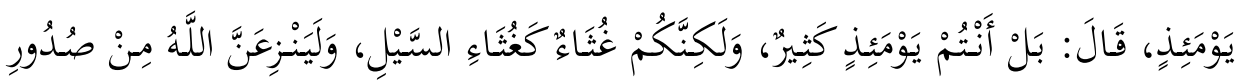

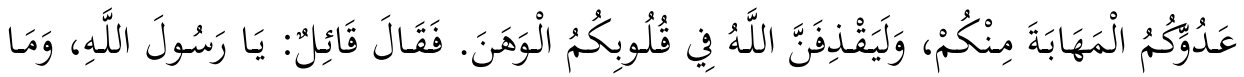

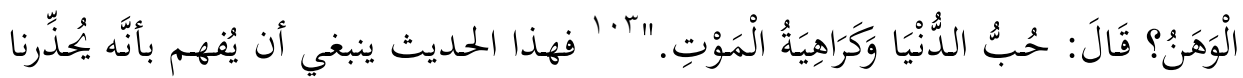

$$
\begin{aligned}
& \text { r.' مسلم، الجامع الصحيح، مرجع سابق، حديث رقمبع ع . انظر أيضاً: }
\end{aligned}
$$

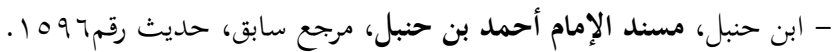

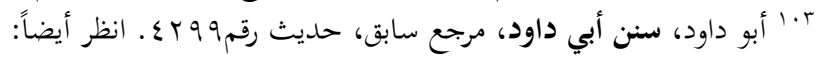

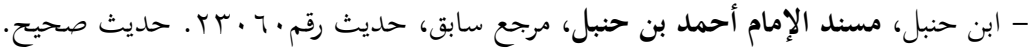

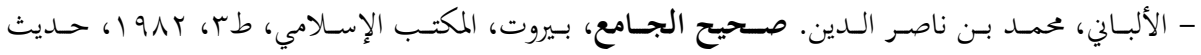

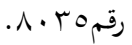


مـ مغبَّة الفرقة والاختلاف؛ وذلك باجتناب حُبِّ الدنيا وكراهية الموت، وأنَّهَ في حسال حصل الذي حذَّرنا منه بتقصيرنا فعلينا أن نسعى أيضاً للعلاج، لا أن نستسلم.

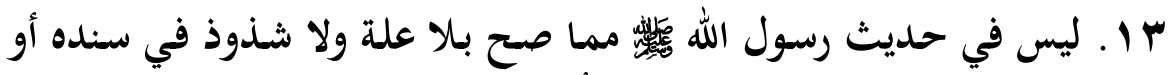

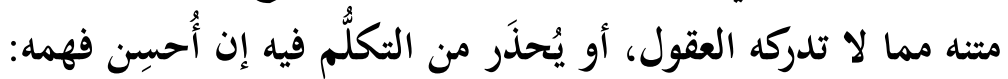

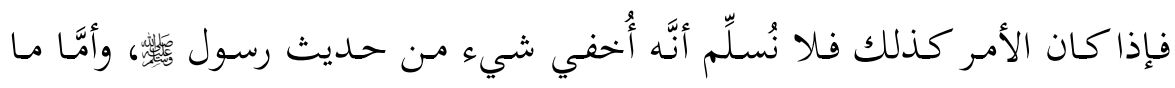

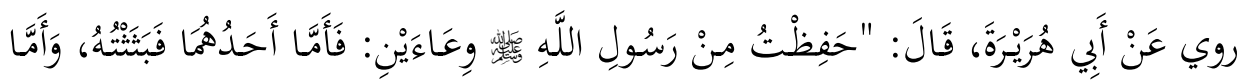

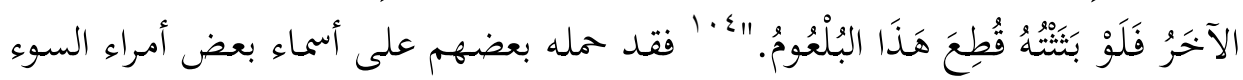

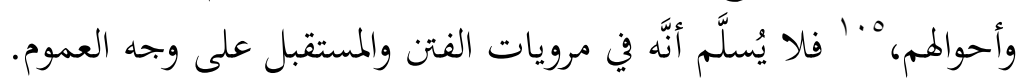

وقد يقـول قائل: نحن مـأمورون بـأن نحـدِّث النـاس بمـا يعقلون، فليس كل مـا يعلم يقال، ولا كل صحيح صالح للنشر؛ لقصور العقول أحياناً عن تحمُّله، أو لسوء التعامل

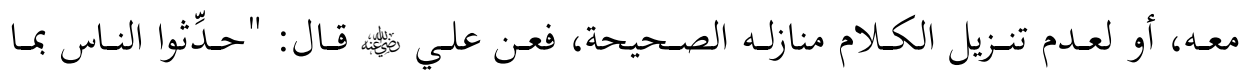

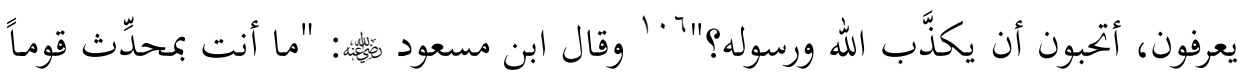

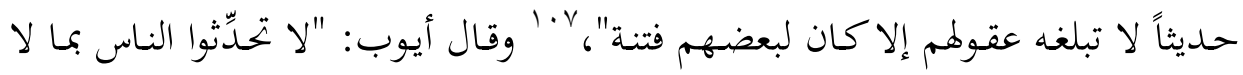

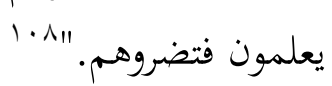

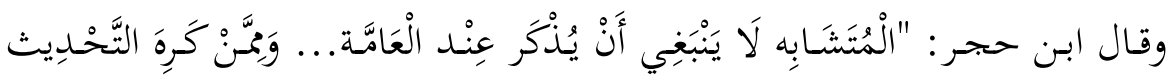

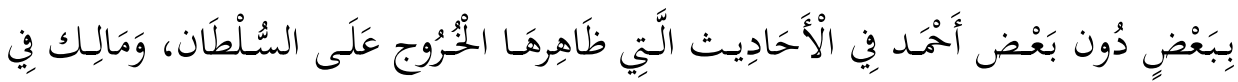

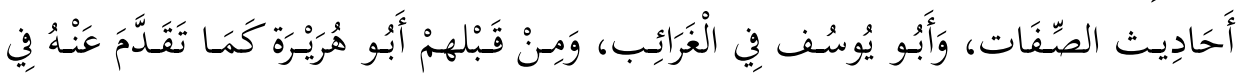

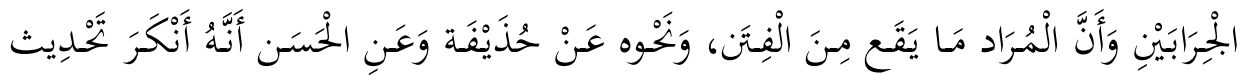

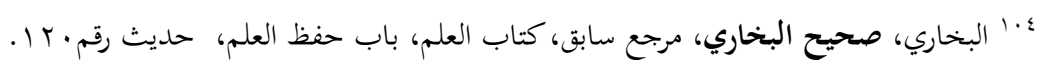

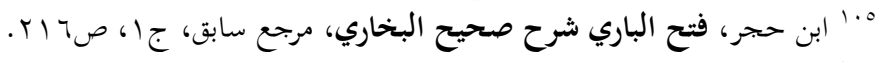

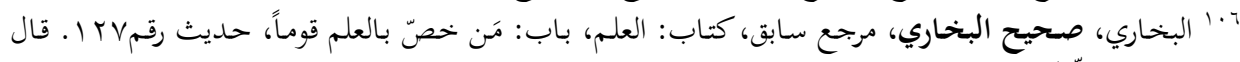

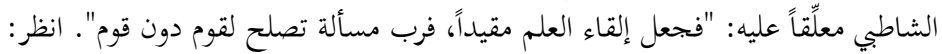

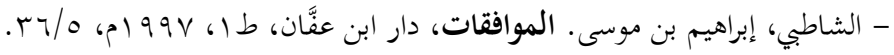

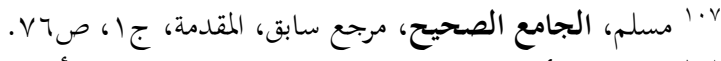

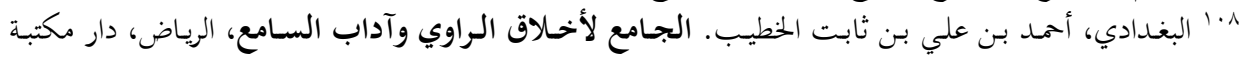




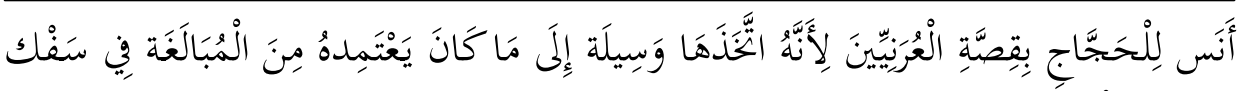

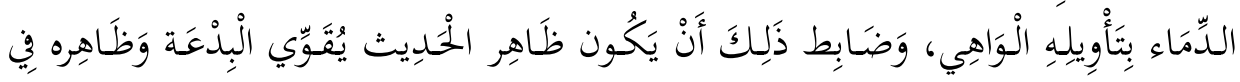

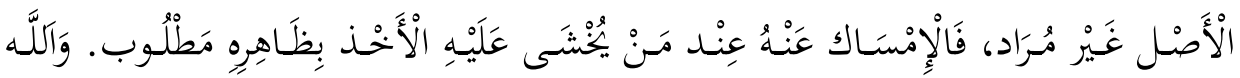

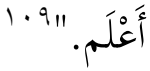

أقول: هذا الأمر يتعلق بالقالب الذي يقدَّم به العلم، ومدى ملاءمة المقام للتحديث

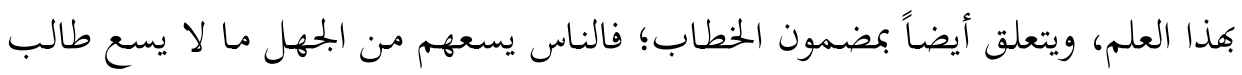

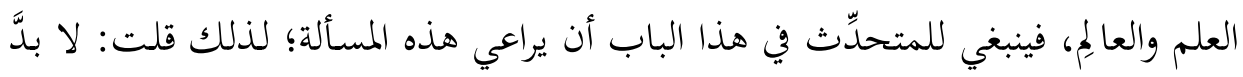

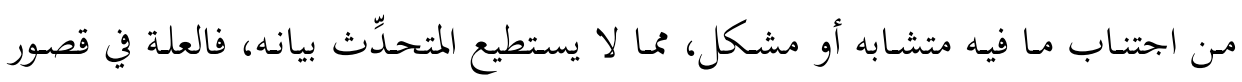

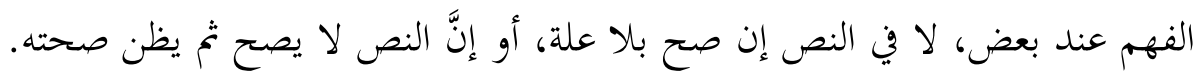

ـ أ. التعامل مع نصوص الفتن والمستقبل على وجه الاحتمال والظن الغالب إذا صحَّت بلا علة، وعدم الجزم على وجه القطع واليقين:

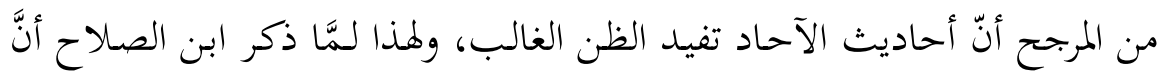

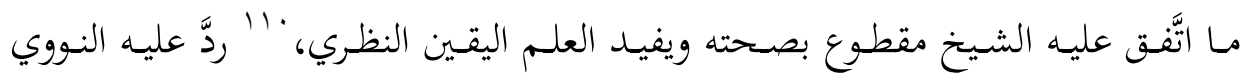

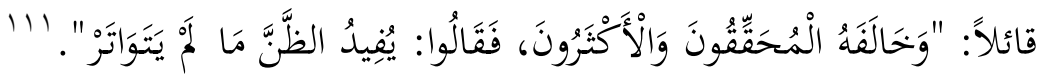

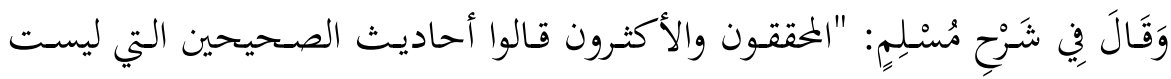

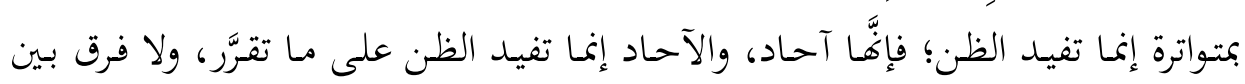

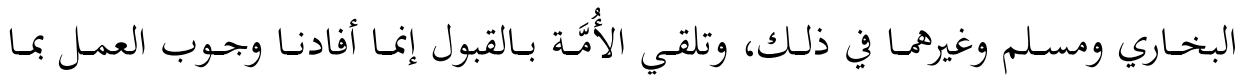

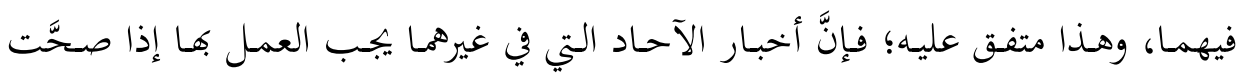

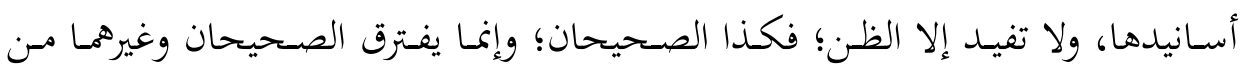

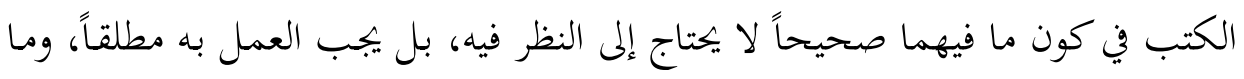

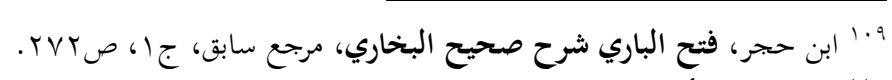

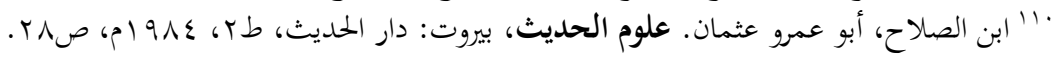

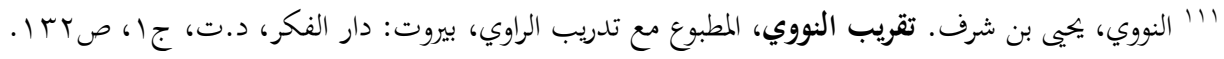


كان في غيرهم لا يعمل به حتى ينظر وتوجد فيه شروط الصحيح، ولا يلزم من إجماع

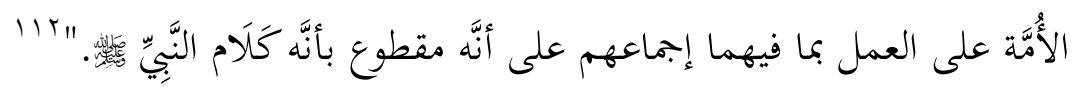

\section{1. الحذر من كل المآخذ والأخطاء الآنف ذكرها:}

ونخص بالذكر منها: إصدار أحكام غير صحيحة على الآخرين، والمبالغة والتهويل،

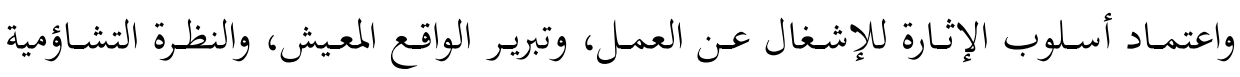

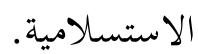

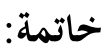

انتهت هذه الدراسة الموجزة في كيفية التعامل مع أحاديث الفتن والمستقبل إلى نتائج

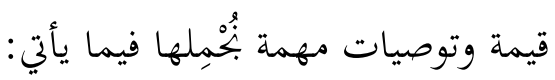

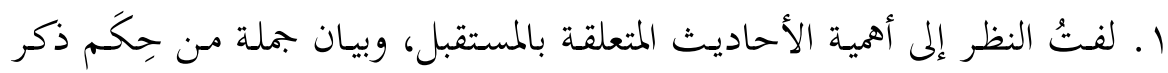

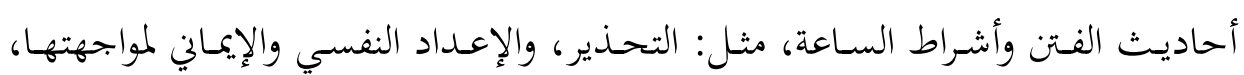

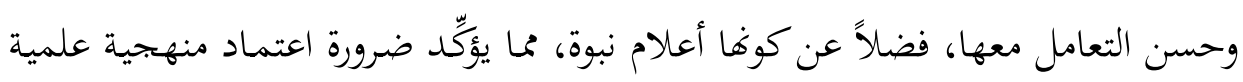

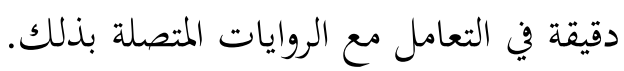
r. الوقوف على جملة مـ الأخطاء والإشكالات التي يقع فيها بعض الباحثين والمدرسين والدعاة، فضلاً عن العامَّة، ومنها: - - عدم التحري الدقيق لصحة الأحاديث. - الاستشهاد بالإسرائيليات. - المات - - رواية أحاديث الفتن لمحرد الإغراب والإمتاع. - عدم القدرة على الفهم الدقيق لبعض الروايات، أو عدم ربطها بالواقع.

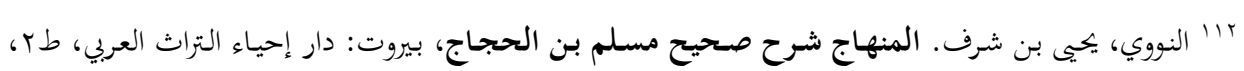
(t) 


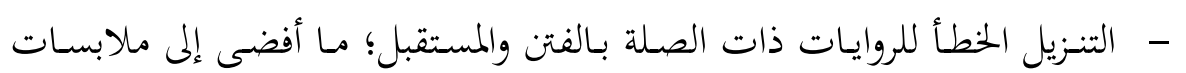

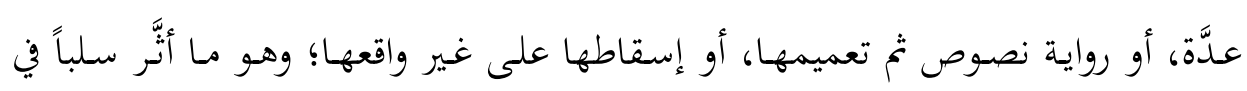

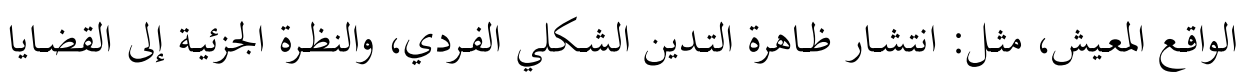

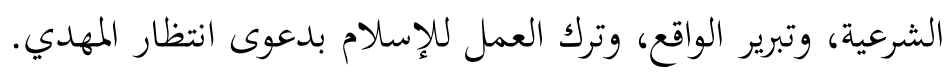
- ادّّعاء تواريخ محدَّدة لوقائع مستقبلية غيبية. - المبالغة والتهويل من غير تحقيق، ولا تمحيص. - - الوقوع في اليأس، وتردّي الحالة النفسية. - إصدار أحكام غير صحيحة في حق الآخرين لسوء الفهم والضبط.

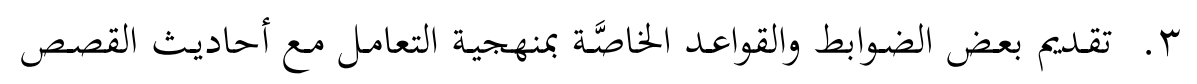

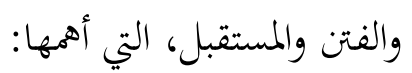
- التحقُق من صحة الحديث؛ سنداً، ومتناً. - - جمع ألفاظ الحديث، وتحري الفهم الدقيق للنصوص، والنظرة الشاملة.

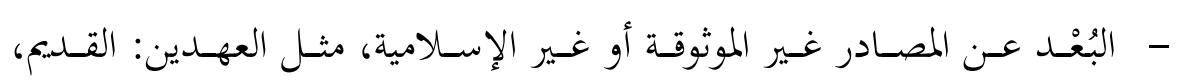
والحديد. - البُعْد عن المشكل، أو ما فيه إغراب. - عدم التكلُف في فهم النصوص، والدقة في التنزيل على الواقع، ومراجعة العلماء المحقِّين. - سياق النصـوص في إطـار بيـان مقاصـدها وِحممها، وكيف نستفيد منها في

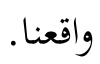
- تجنُّب تحديد تواريخ مستقبلية معينة. - الإيجابية، والبُعْد عن القدرية الاستسلامية في التعامل مع النصوص. 


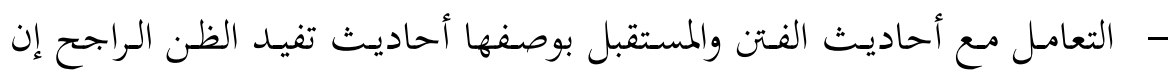
صحَّت، من غير القطع.

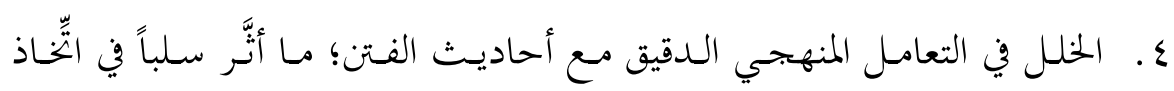

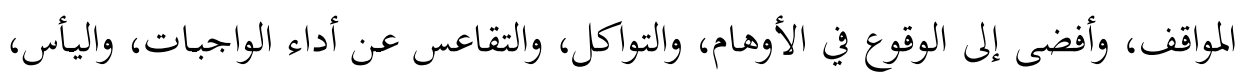

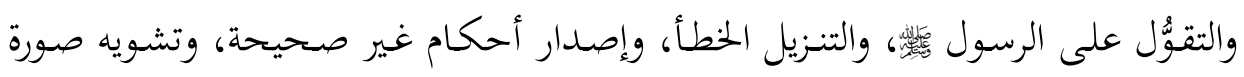

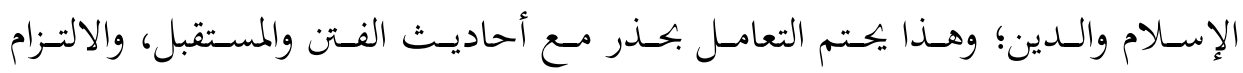
بالضوابط الآنف ذكرها. 